\title{
Observations on some Actinoporellas (Chlorophyta, Polyphysaceae). Revision of the Jacques EMBERGER Collection. Part 1
}

\author{
Bruno Granier ${ }^{1}$
}

\begin{abstract}
On the occasion of the inventory of the J. EMBERGER Collection, specimens from the "Lower Cretaceous" (Valanginian and Hauterivian) of Algeria, which are referable to the genus Actinoporella (GÜMBEL in ALTH) and which were earlier identified to its type-species $A$. podolica (ALTH) by CONRAD et al., are re-examined. They correspond to two discrete species, one of which could be a junior synonym of $A$. podolica, a synonymy that remains pending because it would require a new sampling at the original locality in western Ukraine some 140 years after the original specimens, now lost, were collected. Regarding their age ascription, they are Tithonian and/or Berriasian in age, i.e., latest Jurassic (sensu OPPEL) in age, not earliest Cretaceous. In addition to these two Actinoporellas, a third discrete species, initially described as Clypeina nigra (CONRAD \& PEYBERNĖs), but later referred to the genus Actinoporella, is revised. New data justify its re-ascription to the genus Bakalovaella Bucur. Finally, it is now confirmed that both the Polyphysaceae and the modern Dasycladaceae derive from the Diploporaceae either directly or indirectly through the ancestral Dasycladaceae.
\end{abstract}

\section{Key-words:}

- systematics;

- paleophycology;

- phylogenetics;

- Dasycladales;

- Algeria;

- France;

- Ukraine;

- Tithonian;

- Berriasian;

- Valanginian;

- Hauterivian;

- Barremian

Citation: Granier B. (2019).- Observations on some Actinoporellas (Chlorophyta, Polyphysaceae). Revision of the Jacques Emberger Collection. Part 1.- Carnets Geol., Madrid, vol. 19, no. 7, p. 113-139.

Résumé : Observations sur quelques Actinoporelles (Chlorophyta, Polyphysaceae). Révision de la Collection Jacques Emberger. Part 1.- À l'occasion de l'inventaire de la Collectiony J. Emberger, des spécimens du "Crétacé inférieur" (Valanginien et Hauterivien) d'Algérie, qui se rapportent au genre Actinoporella (GÜMBEL in ALTH) et qui avaient précédemment été attribués à son espèce type $A$. podolica (ALTH) by CONRAD et al., sont réexaminés. Ils correspondent à deux espèces distinctes, dont l'une pourrait être un synonyme junior d'A. podolica, une synonymie en suspens parce qu'elle nécessiterait un nouvel échantillonnage de la localité originelle d'Ukraine occidentale quelque 140 années après que le matériel type, aujourd'hui perdu, y ait été récolté. Concernant l'attribution stratigraphique, ils sont d'âges tithonien et/ou berriasien, c'est-à-dire du Jurassique terminal (sensu OPPEL) et non du Crétacé basal. En plus de ces deux Actinoporelles, une troisième espèce, originellement décrite comme Clypeina nigra (CONRAD \& PEYBERNÈS), mais ultérieurement attribuée au genre Actinoporella, est révisée. De nouvelles données justifient sa réattribution au genre Bakalovaella BUCUR. Enfin, il est désormais confirmé que les Polyphysaceae et les Dasycladaceae modernes sont issues de Diploporaceae, soit directement, soit indirectement par le biais des Dasycladaceae ancestrales.

1 Dépt. STU, Fac. Sci. Tech., UBO, 6 avenue Le Gorgeu, CS 93837, F-29238 Brest (France) bgranier@univ-brest.fr

Published online in final form (pdf) on May 31, 2019

[Editor: Michel MOULLADE; language editor: Phil SALVADOR; technical editor: Bruno GRANIER] 


\section{Mots-clefs :}

- systématique ;

- paléophycologie ;

- phylogenétique ;

- Dasycladales :

- Algérie :

- France ;

- Ukraine ;

- Tithonien ;

- Berriasien

- Valanginien ;

- Hauterivien ;

- Barremien

\section{Introduction}

During his career, the late Jacques EMBERGER (02/01/1923-09/03/1978), son of Louis EMBERGER (23/01/1897-30/11/1969), assembled a private library of scientific literature (offprints, periodicals, books, ...) dedicated to the calcareous algae. Besides that, he collected a significant number of samples of which thin sections were prepared. There are more than 9000 references in this collection, with up to 10 thin sections for each sample. A fraction of this material that corresponds to igneous and metamorphic rocks has been put aside. More recently, some more material was taken out of the collection: that was the type-material of algae studied by Mme Marie LEMOINE, which was shipped to the Muséum d'Histoire Naturelle de Paris for integration in her collection of calcareous red algae. Despite that, the J. EMBERGER Collection remains a very valuable resource for paleophycological investigations (see GrANIER, 1989, 2018a, 2018b). J. EMBERGER was not a prolific author. As a matter of fact, he is mostly known for the bibliographic syntheses that he published in the "Bulletin de l'Institut de Géologie du Bassin d'Aquitaine" (J. EMBERGER, 1976, $1978,1979)$ but he wrote very few contributions dedicated to the algae (J. EMBERGER, 1956, 1958a, 1958b, 1958c; J. EMBERGER \& MAGNÉ, 1957; M. Lemoine \& J. Emberger, 1967; CAnÉrot \& J. EMBerger, 1970; Bulle \& J. EMBerger, 1973). He did not pay either much attention to formally define some taxa of his own. That was the case with his "Zergatella suprajurensis" ( $\mathrm{J}$. EMBERGER, 1960; GRANIER, 1989, 2010) but that was also the case with his "Clypeina harrazaensis" (J. EMBERGER, 1960), which is one of the species described in this first part of the "Revision of the Jacques EMBERGER Collection", together with Clypeina lucasi J. EMBERGER, 1956. Both Clypeinas are referable to the genus Actinoporella (GüMBEL in ALTH, 1882). Although J. EMBERGER did not identified it his collection includes a third species that was once considered as another Actinoporella; it will prove to be a Dasycladacean, not a Polyphysacean alga.

\section{A digest on Actinoporella podolica (ALTH, 1878)}

ALTH (1878: PI. VI, figs. 1-8; herein Fig. 1) describes Gyroporella podolica from Upper Jurassic limestones of the locality of Nyzhniv ("Niżniow") and of its immediate vicinity ("góry Tanutyńskiéj" / "Tanutynska Gora"): Fig. 2 . He also mentions two other localities of the Ivano-Frankivsk Oblast in W Ukraine: Bukivna ("Bukowna", some $10 \mathrm{~km} \mathrm{~W}$ of Nyzhniv) and Kutyshche ("Kutysk", some $5 \mathrm{~km} \mathrm{~S}$ of Nyzhniv), where the alga is less common. Later, GüMBEL (in ALTH, 1882) introduces the genus Actinoporella based on Gyroporella podolica (ALTH, 1878, PI. VI, figs. 1-4, 6-8), whereas ALTH (op.cit.) introduces a new species "Actinoporella Gümbeli" based on specimens originally ascribed to Gyroporella podolica (ALTH, 1878, PI. VI, fig. 5). However, after comparing 40 specimens ascribed to Actinoporella podolica and 13 specimens of Acti-noporella guembeli, PIA (1920) concludes that both species are synonymous. ALtH's, GüMBEL's and PIA's materials are lost. They were probably destroyed during the Second World War (CONRAD et al., 1974).

The original locality of each specimen illustrated by ALTH (1878, PI. VI, figs. 1-8; here Fig. 1) is not provided, which is not the case with PIA's (1920, PI. VII, figs. 1-7; herein Fig. 3) drawings but there are other issues:

- according to ConRAD et al. (1974), two specimens they illustrate (op.cit., Fig. 7.a-b), which "are reminiscent of the specimen" on PIA's figure 1 of plate VII (1920), "are attributable to a new species of Clypeina or Teutloporella";

- $\quad$ according to RADOIČić (1969), PIA's figure 3 of plate VII (1920) is "very different from ALTH's specimens of Actinoporella podolica, and might correspond to some mesozoic [sic] Clypeina" (ConRAD et al., 1974). PiA's (1920: Fig. 19) erroneous reconstruction of the species, reused by Berger and KAeVer (1992: Fig. 2.20.e), is based on this single specimen;

- PIA's figure 4 of plate VII (1920) is also questionable (see discussion below). 

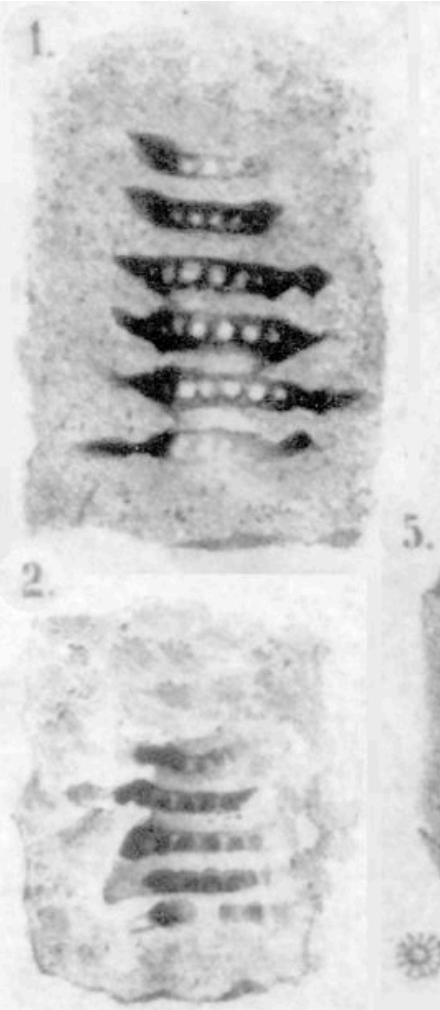

3.

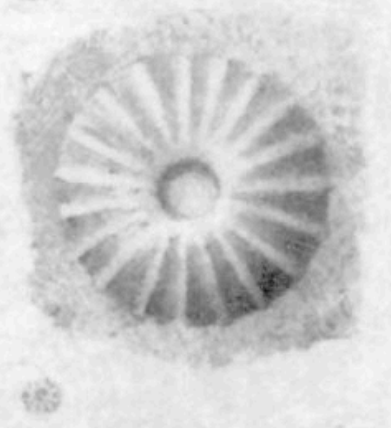

5.

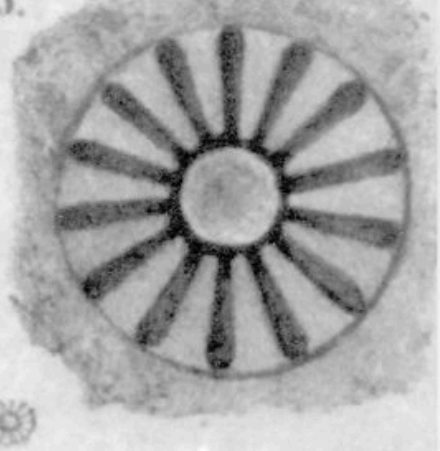

4

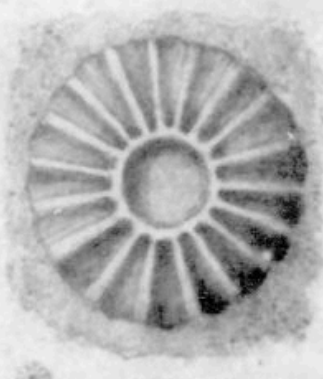

$\uparrow$

6.

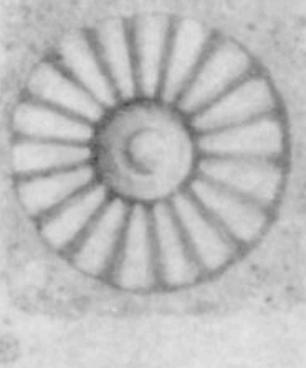

8.

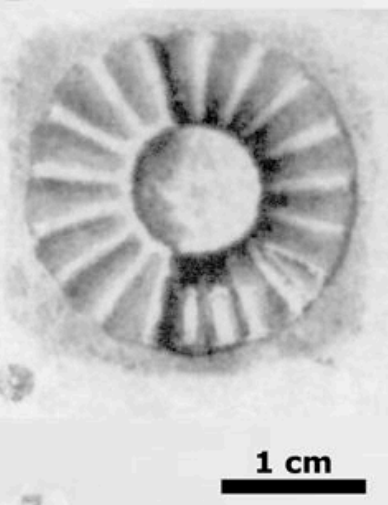

7.

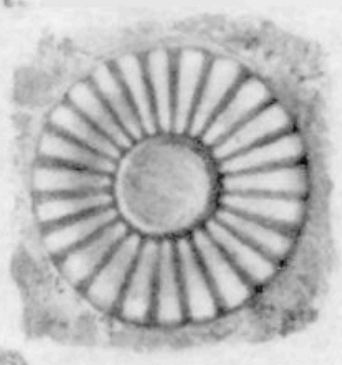

Figure 1: Gyroporella podolica fide ALTH (1878). 1) oblique break; 2) oblique break; 3) mould of whorl; 4) mould of whorl (corresponding to imprint 6); 5) imprint of whorl (corresponding to "Actinoporella guembeli ALTH, 1882"); 6) imprint of whorl (corresponding to mould 4); 7) imprint of whorl; 8) mould of whorl. Scale bar $1 \mathrm{~cm}$ (from the book).

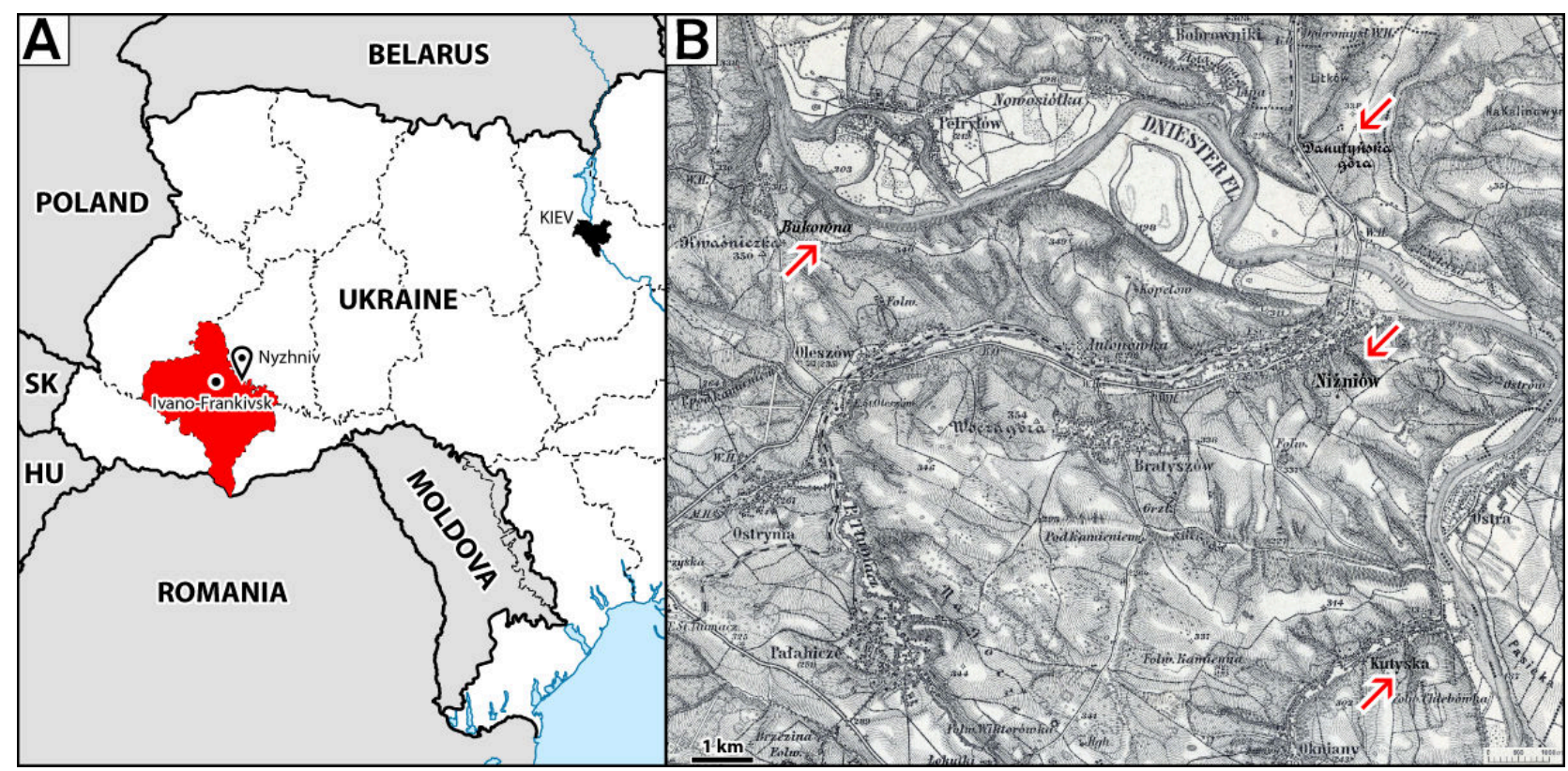

Figure 2: Location map of the original localities sampled by ALTH (1878) in the Nyzhniv area, W Ukraine: "Niżniow", "Danutyńska góra", "Bukowna", "Kutysk. 


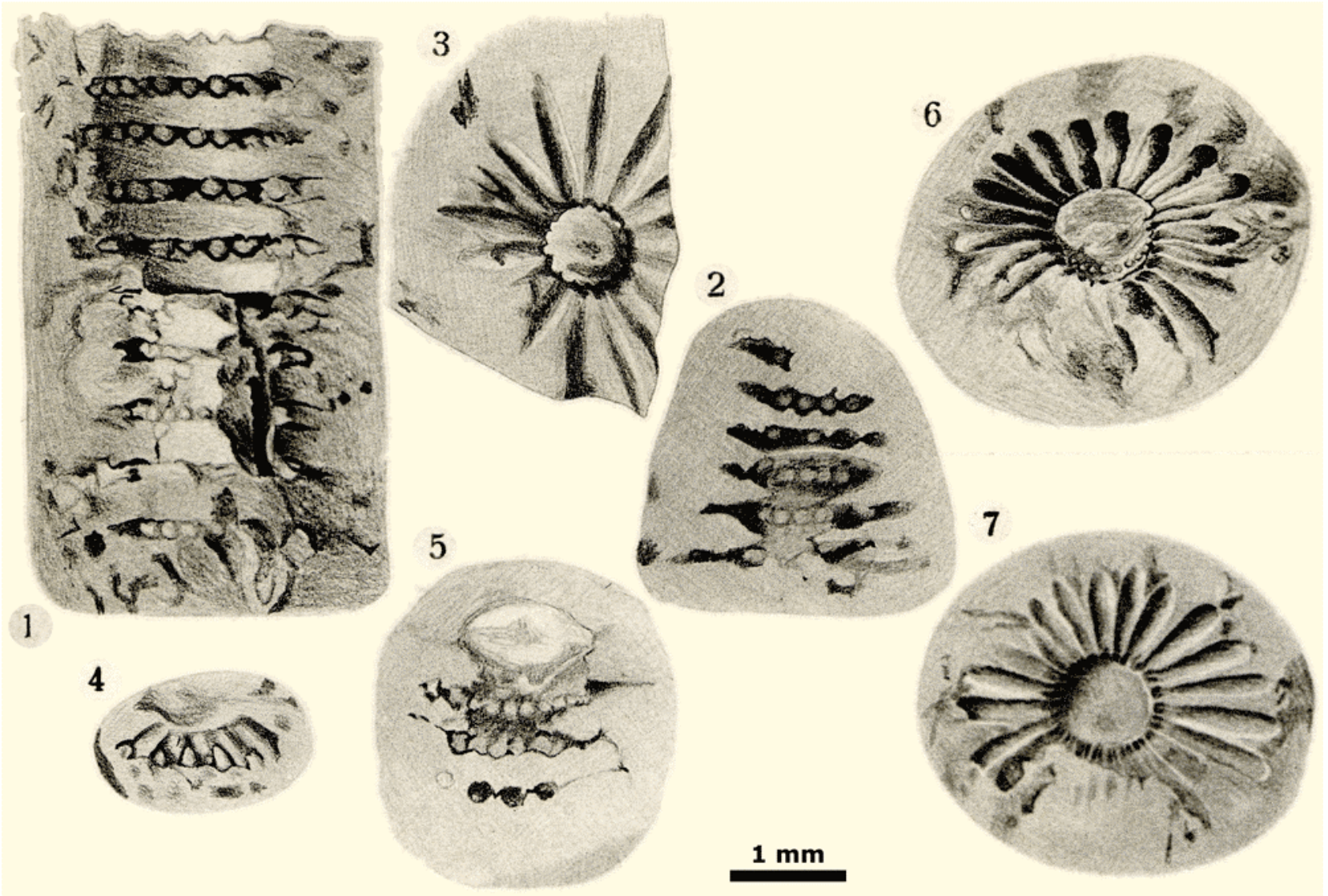

Figure 3: Actinoporella podolica fide PIA (1920). 1) longitudinal break; 2) oblique break; 3) mould of whorl; 4) imprint of whorl; 5) oblique break; 6) mould and 7) imprint of whorl.

Scale bar $1 \mathrm{~mm}$.

The specimens illustrated on PIA's figures 1 and 4 of plate VII (1920) were collected at "Tanutynska Gora" whereas the specimen illustrated on figure 3 was collected at Bukivna. In conclusion, one is left with four of PIA's figures (1920, PI. VII, figs. 2, 5-7) of specimens that were all collected at Nyzhniv:

- PIA's figure 2 of plate VII (1920), which corresponds to ALTH'S figure 1 of plate VI (1878), and PIA's figure 5 of plate VII (1920). Both of them are oblique breaks;

- PIA's figures 6 and 7 of plate VII (1920), which are respectively the mould and the imprint of the same single whorl.

In conclusion, the type locality of Actinoporella podolica should be Nyzhniv itself, not "Tanutynska Gora" as stated by ConRAD et al. (1974). This toponym, which is not visible on Alth's map (1882, p. 185), was misspelled for "Danutyńska góra", as reported on the 1:75,000 military map of "Tyśmienica und Tłumacz" (1877-1912). Relative to Nyzhniv, it is located on the opposite bank of the river Dniester, and corresponds to Dibrova, IvanoFrankivsk Oblast.

In a subchapter entitled "Actinoporella podolica in its type-locality of Upper Jurassic age", CONRAD et al. (1974) state that "the reason why the dimensions given by" PIA "for $d$ and D are different from" their "own observations is not known". However, it is crystal clear:

- their material was not collected at Nyzhniv, the type-locality, but probably in another locality;

- the measurements of their specimens are not only "different" but significantly out of ranges compared to those given by ALTH (1878) and PIA (1920). For instance, $D$, the diameter of a whorl, is significantly smaller, ranging from 2.1 to $3.2 \mathrm{~mm}$ according to PIA (1920) versus from 0.7 to $1.0 \mathrm{~mm}$ according to CONRAD et al. (1974); similarly, $d$, the diameter of the main axis, ranges from 0.4 to $1.1 \mathrm{~mm}$ according to PIA (1920) versus from 0.18 to $0.28 \mathrm{~mm}$ according to CONRAD et al. (1974);

- most specimens of figure 6 of CONRAD et al. (1974: Fig. 6.a-f) are "poorly preserved". It looks like they consist of mouldic pores, left empty after the leaching of the original aragonitic coating;

- their figures 4.a-b (CONRAD et al., 1974; herein Fig. 4.a-b) and 6.g (CONRAD et al., 1974; herein PI. 1, fig. a) might correspond either to Clypeina ? isabellae MASSE et al., 1999 (see PI. 1, figs. b-f), or to Clypeina ? loferensis SCHLAGINTWEIT et al., 2009. 

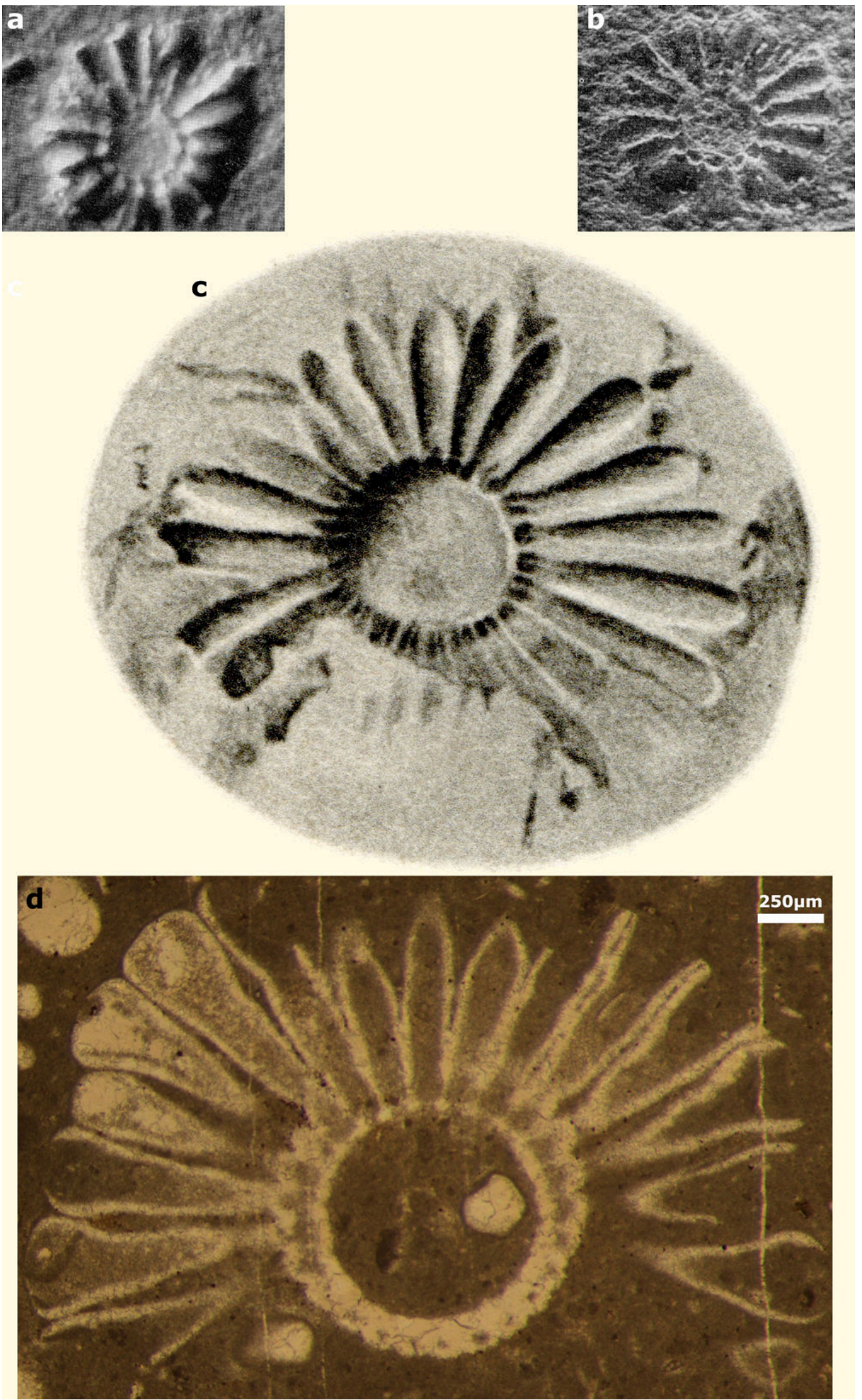

Figure 4: a-b) 14-15 laterals, excerpts from ConRAD et al. (1974: Fig. 4.a-b); c) 22 laterals, excerpt from PIA (1920: PI. VII, fig. 7); d) holotype of Actinoporella harrazaensis n.sp., subtransverse section of a single row with 25 clubshaped laterals, thin section 444B. See J. EmBERGER's 1960 Fig. 27 (Djebel Harraza, J. EmBERGER Collection). Scale bar $250 \mu \mathrm{m}$. 
All that suggests that one should seriously question the identification of CONRAD et al.'s (1974) new material as Actinoporella podolica (ALTH, 1878), as well as the relevancy of their synonymy list.

\section{Actinoporella specimens from Algeria}

In a subchapter entitled "On Clypeina lucasi ( $=A$. podolica $)$ and other specimens from the Neocomian age", ConRAD et al. (1974) state that Clypeina harrazaensis, nom. nud. (J. EMBERGER, 1960), from the Hauterivian of Algeria, and Clypeina lucasi J. EMBERGER, 1956, from the "Valanginian" of Algeria, are junior synonyms of Actinoporella podolica. However, pending a new survey of the Ukrainian type-locality, the result of which would provide a conclusion to the synonymy of one of these Algerian species with Actinoporella podolica, it is assumed below that we are dealing with two discrete species.

Remains of the first species mostly consist of isolated rows with in average 15 subcylindrical fertile ampullae that, due to their morphology, are distally diverging (PI. 2) whereas the rows of the second species bear up to 25 phloiophorous fertile ampullae forming a rather continuous "clipeus" (Fig. 4.d).

\section{Actinoporella harrazaensis J. EMBERGER eX GRANIER, herein}

(Fig. 4.d; PI. 3, figs. a-h; PI. 4, figs. a-j; PI. 5, figs. a-n; PI. 6, figs. a-d)

Synonymy:

nom. nud. 1960 Clypeina harrazaensis n.sp.- J. EMBERGER, p. 143, Fig. 27 (1) (herein Fig. 4.d; PI. 4, figs. $a-b, g)$

1972 Clypeina lucasi.- REY, PI. VIII, fig. 2

1974 Actinoporella podolica.- CONRAD et al., Fig. 9.aC

1992 Actinoporella lucasi n.comb.- GranieR, PI. 1, figs. 5-6

Origin of the name: from Djebel Harraza (Aïn Rich, Algeria).

Holotype: Fig. 4.d, also illustrated by J. EMBERGER (1960: Fig. 27.1 pars), subtransverse section of a single row, thin section 444B, J. EMBERger Collection.

Paratypes : PI. 3, figs. a-h; PI. 4, figs. a-e, g, $i-j$; PI. 5, figs. a-n, various subaxial, tangential and oblique sections 444A, 444B, 444C, 444D, $444 \mathrm{E}$, and $444 \mathrm{~F}$ from the same rock sample.

Type-level: In level 15 of the Djebel Harraza section (J. EMBERGer, 1960: Fig. 26), it is found associated with Pseudocyclammina lituus (YoKoYAMA) and Coscinoconus sp. In the Djebel Ladjdar section (e.g., in sample 873 of the J. EMBERGER Collection, "Ain Melah" (Aïn El Melh), S of Bou-Saâda), it is found with calpionellids. Accordingly it is not "Hauterivian" in age as suggested by ConRAD et al. (1974), but Berriasian.
Diagnosis: A rather large representative of the genus Actinoporella (GüMBEL in ALTH, 1882), commonly found in the form of dissociated fertile rows, ranging from 1.5 to $3.2 \mathrm{~mm}$ in diameter. Presence of both upper and lower coronae. About two dozens of club-shaped fertile ampullae per row forming a flat clipeus-like verticil. These morphologic and metric (below) parameters are diagnostic of the species.

Description and measurements: The photomicrographs (Fig. 4.d; PI. 3, figs. a-h; PI. 4, figs. a-j; PI. 5, figs. a-n; PI. 6, figs. a-d) represent a comprehensive catalogue of the material referable to this species found in the J. EMBERGER Collection. A unique large subtransverse section of a row comprising some 25 laterals (Fig. 4.d), already illustrated by J. EMBERGER (1960: Fig. 27.1 pars), is selected as the holotype. Its outer diameter $D$ is $3.2 \mathrm{~mm}$ whereas its inner diameter $d$ is $0.88 \mathrm{~mm}$, which results in a d/D ratio of $27.5 \%$. Some specimens are smaller, with $\mathrm{D}$ equal to $1.5 \mathrm{~mm}$, but the distal part of the lateral was not preserved. With d equal to $0.33 \mathrm{~mm}$; the ratio $\mathrm{d} / \mathrm{D}$ varies from $18.8 \%$ to $37.6 \%$. The thickness/height of a whorl, $\mathrm{H}$ (comprising the coronae), measures $0.46 \mathrm{~mm}$ in average. The fertile ampullae are typically club-shaped with a width increasing gradually from $0.09 \mathrm{~mm}$ in the proximal part up to $0.33 \mathrm{~mm}$ in the distal part. They are probably slightly vertically compressed, i.e., thinner (in axial or tangential sections) than wider (in transverse section), and their length may exceed $1 \mathrm{~mm}$. Some measurements (d/D, w) make it close to Actinoporella guembeli sensu ALTH (1882); however, it is still not possible to conclude to a synonymy because ALTH 's original material is lost.

\section{Actinoporella lucasi (J. EMBERGER, 1956), GRANIER, 1992}

(PI. 2, figs. a-f, g pars; PI. 6, figs. e, g-k; Pl. 7, figs.a-g)

Synonymy:

1956 Clypeina lucasi n.sp.- J. EMBERGER, p. 549-550, Fig. 3 pars; PI. XXIV, figs. 1-2 (holotype), 7 pars

1960 Clypeina lucasi.- J. EMBERGER, Fig. 21.1

1974 Clypeina lucasi EMBERGER (= Actinoporella podolica).- CONRAD et al., Fig. 8.a-b

? 1966 Clypeina aff. hanabatensis n. sp.- MouTY, PI. 4, figs. 1-2

non 1992 Actinoporella lucasi n.comb.- GranieR, PI. 1, figs. 5-6

According to CONRAD et al. (1974), "the thalli (...) are hollow and epigenized by large dolomite rhombs" and "no suitable sections could be made". However, in addition to the isolated rows (J. EMBERGER, 1956: Fig. 3 pars; PI. XXIV, figs. 1-2, 7 pars; CONRAD et al., 1974: Fig. 8.a-b; herein: PI. 2, figs. a-f, g pars), there is a significant number of thin sections made from the same rock samples in the J. EMBerger Collection (herein: PI. 6, figs. e, g-k; PI. 7, figs. a-g). 
According to J. EMBERGER (1956), the outer diameter $D$ of a whorl ranges from 2.5 to 3.0 $\mathrm{mm}$ and the inner diameter $\mathrm{d}$ ranges from 0.35 to $0.48 \mathrm{~mm}$. The distal part of the fertile ampullae is commonly broken. Two isolated rows with some complete ampullae are measured: A) PI. 2 , fig. a sample has $D=2.2 \mathrm{~mm}$ with $\mathrm{d}=0.4$ $\mathrm{mm}$, i.e., $\mathrm{d} / \mathrm{D}=18 \%$, and B) PI. 2, fig. b sample has $D=2.9 \mathrm{~mm}$ with $\mathrm{d}=0.5 \mathrm{~mm}$, i.e., again $d / D=18 \%$. In thin section, because measurements of $D$ are commonly underestimated and $d$ ranges from 0.33 to $0.65 \mathrm{~mm}$, the ratio $d / D$ is commonly overestimated (it reaches up to $25 \%)$. The thickness of a whorl, i.e., its height, $\mathrm{H}$ (comprising the coronae), ranges from 0.3 to $0.5 \mathrm{~mm}$, and is probably almost equal to the distance from the center of a whorl to the center of the next one, $h$. Accordingly, the ratio $\mathrm{H} / \mathrm{h}$ should be close to 1 . The diameter of the fertile ampullae, $\mathrm{p}$, may reach up to 0.56 $\mathrm{mm}$ at their distal part (versus $0.5 \mathrm{~mm}$ according to J. EMBERGER, 1956), and their length may exceed $1 \mathrm{~mm}$ (up to $1.1 \mathrm{~mm}$ according to J. EMBERGer, 1956). The number of ampullae per whorl is 15 in on average. Some values (d/D, w) make it close to Actinoporella podolica sensu ALTH (1882). As for A. harrazaensis n.sp. above, it is not possible to conclude on their synonymy.

Remark: In the Djebel Ladjdar section (J. EMBERGER, 1960: Fig. 20), this species is found associated with Salpingoporella annulata CAROzZI and Coscinoconus sp., below strata with Anchispirocyclina lusitanica (EGGER) and calpionellids. Accordingly it is not "Valanginian" in age as suggested by CONRAD et al. (1974), but probably Tithonian - (?) early Berriasian.

\section{Notes on Actinoporella nigra (CONRAD \& PEYBERnès, 1978), GRANIER, 1994 \\ Bakalovaella nigra \\ Conrad \& Peybernès, 1978, n.comb.}

$$
\text { (PI. 1, figs. g-ab, ae-ak) }
$$

Synonymy:

1976 Clypeina sp. 1.- ConRad \& PeYbernès, p. 180, Fig. 6

1978 Clypeina nigra n.sp.- CONRAD \& PEYBERnÈs, p. 80-82, Figs. 1, 2 (= CONRAD \& PEYBERnĖs, 1976: Fig. 6), 3 (holotype), 4-5

1979 Clypeina nigra.- PeYBernès et al., p. 80-82, PI. 3, fig. 4

1980 Clypeina nigra.- ARnAUd-VANNEAU, PI. 112, figs. $1-3$

1994 Actinoporella nigra n.comb.- GRANIER, p. 114115, Pl. 3, figs. 1, 2 (= ARNAUd-VANNEAU, 1980, PI. 112, fig. 2), 3 (= ARnAUd-VANneau, 1980, Pl. 112, fig. 3), 4

2002 Actinoporella nigra.- BUCUR, p. 44, PI. III, fig. 7
A set of ten thin sections, 4 labelled 7237 and 6 more labelled 7238 , with the alga was identified in the J. EMBERGER Collection. The rock samples were picked from core 4 of the Esso REP STE1 borehole, at Saint-Trosse (Municipality of Pontenx-les-Forges, Landes, France). The borehole location, WGS84 $44^{\circ} 17^{\prime} 39.0^{\prime \prime} \mathrm{N} 1^{\circ} 03^{\prime} 17.0^{\prime \prime} \mathrm{W}$, is derived from the Infoterre website of the B.R.G.M. (2019).

According to ConRAD and PeYbernès (1976), the diagnosis is "Small, simple and cylindrical thallus, bearing laterals arranged in regularly spaced whorls. Club-shaped laterals, closed at their distal ends, filled in with hyaline calcite, and connected to the axial siphon by a narrow pore. The siphon as well as the laterals are embedded in a black and microgranular carbonate cast. The non-calcified space separating the whorls is divided by fine radial partition walls that are also microgranular in nature" [translated from the French: "Petit thalle simple et cylindrique, porteur de rameaux disposés en verticilles régulièrement espacés. Rameaux en forme de massue, fermés à leurs extrémités distales, garnis de calcite hyaline, et communiquant avec le siphon axial par un pore étroit. Le siphon, ainsi que les rameaux sont enrobés par une masse carbonatée noire et microgranulaire. L'espace non calcifié séparant les verticilles est parcouru par de fines cloisons radiales, également de nature microgranulaire"].

According to Granier (1994), the amended diagnosis is "Small articulated Actinoporella species with a cylindrical main axis bearing close-set whorls of branches. Branch consisting of a vestibule followed by a vesicular to short club-shaped gametophore, by an open pore on one side of the whorl, and by an "excrescence" on the opposite side. Gametophore perpendicular to the main axis and closed at its distal part. Calcareous sheath consisting of microgranular calcite wall".

The algal structure is fully reinterpreted here (Fig. 5). The ampulla is ovoid and short, which can hardly compare with the long ampullae of the Actinoporellas. The "excrescence" of GrANIER (1994), visible on one side of the whorl, at the base of the ampulla, could be an artifact whereas the pore on the opposite side of the whorl is effectively connecting the ampulla to the sterile lateral. Those structures observed in the interverticillar space and described by CONRAD and PEYBERNĖs (1976) as "cloisons radiales (...) microgranulaires" or as "indentations de l'enveloppe calcaire entre les verticilles" correspond to poorly mineralized walls between neighbouring sterile laterals. The structure of the alga is that of a Bakalovaella (see GRANIER \& BUCUR, 2019), hence the new combination. 

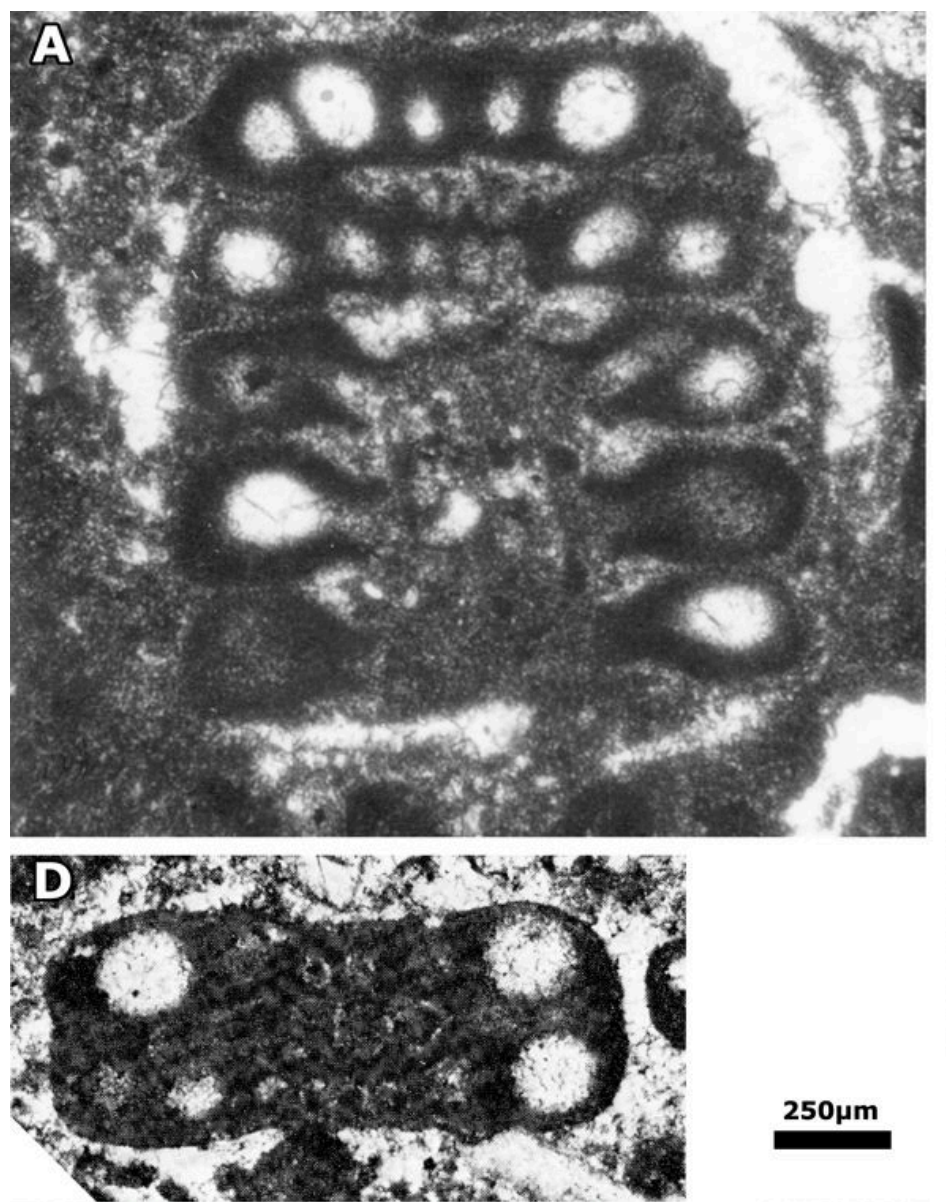

$$
\text { A* }
$$
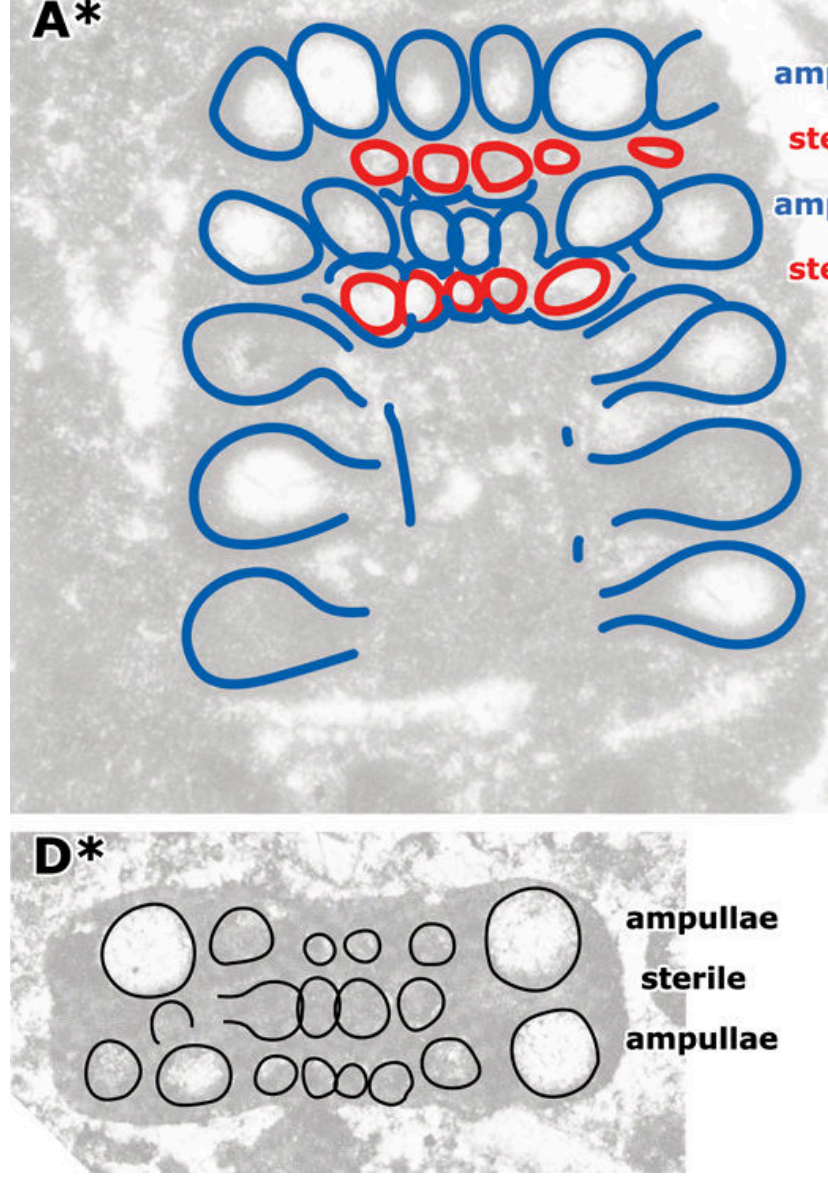
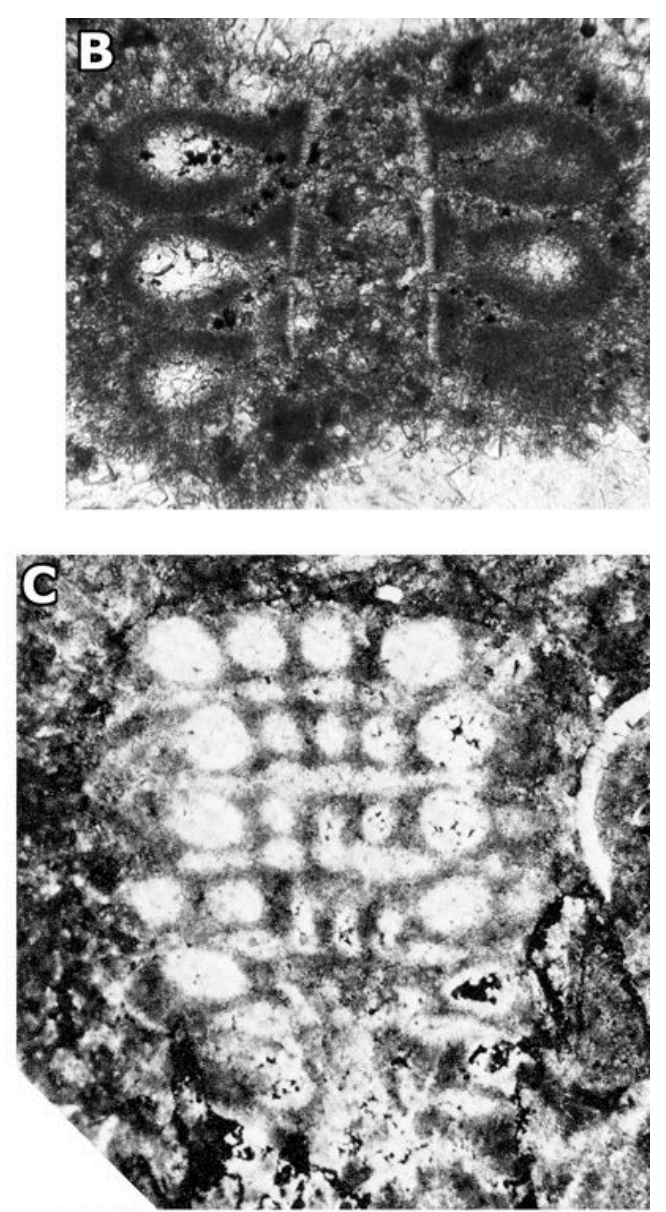

B*

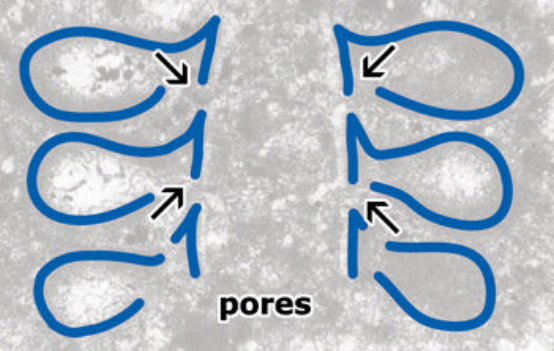

\section{C*}

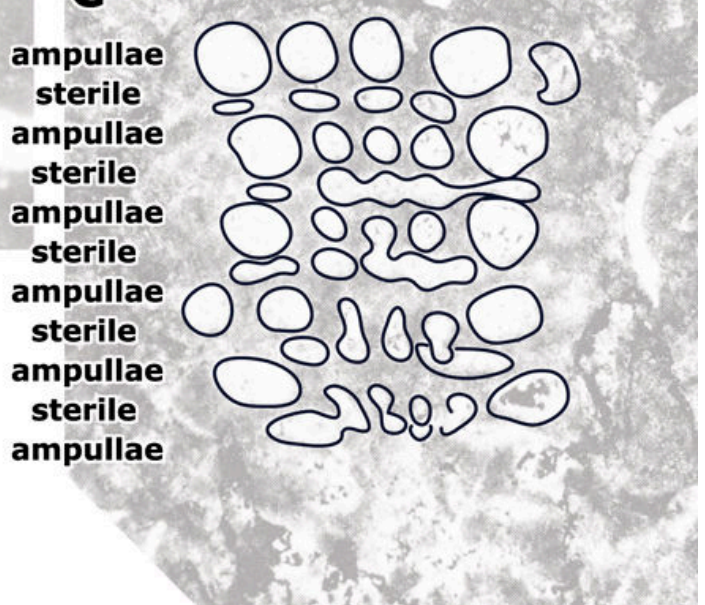


Figure 5: Bakalovaella nigra (CONRAD \& PEYBERNÈs), n.comb. A-A*) subaxial to oblique section with 5 whorls. Unpublished photomicrograph by J. EMBERGER, STE1, Saint-Trosse, France; B-B*) subaxial section with 3 whorls. Excerpts from GRANIER, 1994: PI. 3, fig. 1. É. FOURCADE Collection, sample G.1280, Spain; C$C^{*}$ ) tangential section with 6 whorls. Excerpt of CONRAD \& PeYBernès, 1978: Pl. II, fig. 2. PeYbernès Collection, Bas de Cagire, France; D-D*) tangential section with 2 whorls. Holotype, excerpt of CONRAD \& PeYbernès, 1978: Pl. II, fig. 3. PeYBernès Collection, Bas de Cagire, France.

Scale bar $250 \mu \mathrm{m}$.

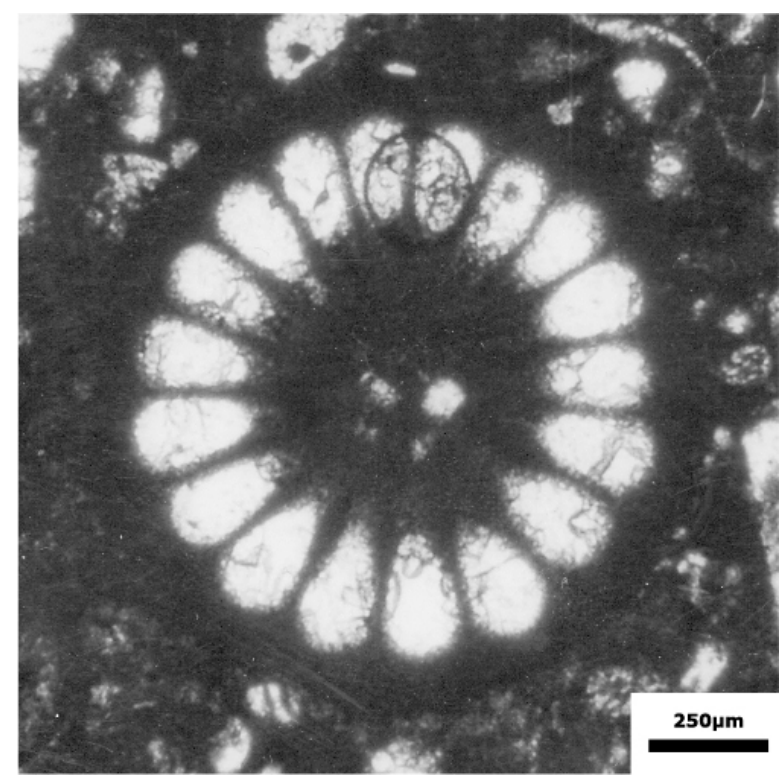

Figure 6 : Bakalovaella nigra (CONRAD \& PEYBERNÈs), n.comb.: transverse section of a whorl with 25 ampullae. Unpublished photomicrograph by J. EMBERGER, STE1, Saint-Trosse, France.

Scale bar $250 \mu \mathrm{m}$.

A transverse section of a whorl in one photomicrograph of the J. EMBERGER Collection (Fig. 6) bears 25 ampullae (compared with 18-20 according to CONRAD and PEYBERNÈs, 1976); it reaches $1.1 \mathrm{~mm}$ in outer diameter (compared with 0.6-0.8 $\mathrm{mm}$ according to CONRAD and PEYBERNÈs, 1976).

At Saint-Trosse, the species is found associated to Choffatella gr. decipiens SCHLUMBERGER and Palorbitolina lenticularis (BLUMENBACH) in strata ascribed to the Barremian-lower Aptian. The specimens from the Rocher de Cluses (PI. 1 , figs. ab, ak) should be refered to the upper Hauterivian. The alga is known from Bulgaria (ConRad \& PeYbernès, 1978; PeYbernès et al., 1979), France (ConRAD \& PeYbernès, 1976, 1978; ARNAUD-VANNEAU, 1980), Romania (BuCUR, 2002), Spain (GRANIER, 1994), and Switzerland (SCHLAGINTWEIT, unpublished data, personal communication, 20/04/2019), all these occurrences are currently restricted to the northern Neotethysian margins.

\section{Elements of phylogeny}

The various use of "vestibule" in modern Polyphysaceae and fossil Diploporaceae generates some confusion because it refers to discrete structures: A) In the living Polyphysaceae, the vestibule is an expansion of the main axis at the base of the fertile lateral, both being separated by a partition with an opening (BERGER \& KAEVER, 1992). Therefore, it comes before the common base of the corona(s) and the fertile ampulla; B) In the Diploporaceae, the vestibule is the common base of a tuft of laterals. In some forms, it can even expand slightly to form some sort of short primary lateral (see discussion in Bucur \& ENos, 2001), called a "composite vestibule" by MAMET and Roux (1981). Accordingly, for some authors, when the primary is much shorter than the secondaries, it could legitimately be called a vestibule.

It was previously suggested that the Family Bornetellaceae Granier \& BUCUR (in Granier et al., 2013) arose from the Family Triploporellaceae (PIA) with transition forms from Triploporella STEINMANN to Zitellina L. et J. Morellet (see Bucur et al., 2010). Similarly, ancestors of the Family Thyrsoporellaceae GraniER \& BUCUR, 2013, should also be found in the Triploporellaceae.

In contrast, the Family Dasycladaceae (KüTZING) probably arose from the Family Diploporaceae (PIA) with possible affiliations of A) Granieria BARATTOLO \& RoMANo to Barattoloporellopsis GRANIER et al. or to Bakalovaella Bucur, then Montiella (L. et J. MORELLET), and of B) Eodasycladus CROS \& LEMOINE to Indopolia PIA and/or to Cymopolia J.V. LAMOUROuX. In both cases ( $A$ and $B$ ), it is assumed that the driving force honoured the "piston lifting" model of GRANIER and BUCUR (2019) rather than the "escalator" model of L. EMBERGER (1968) or the cladospore to choristopore evolution as suspected by ELLIOTT (1989). In the "piston lifting" model, the primary lateral becomes increasingly longer whereas the fertile ampulla remains rather small. Ancestors of the Family Polyphysaceae (KüTZING) should also be found in the Diploporaceae or in ancestral Dasycladaceae (e.g., Eodasycladus) with possible affiliations of Actinoporella to Halycoryne HARVEY and/or Acetabularia J.V. LAMOUROUx. Some sort of "communicating vessels" model should apply here because, in complete contrast to the previous model, the primary remains rather small whereas the fertile ampulla becomes increasingly larger.

Ultimately, it is a different scenario (Fig. 7) than those proposed earlier by micropaleontologists (e.g., Pia, 1920; Elliott, 1989; Granier in Berger et al., 2004) or phycologists (BERGER and KAEVER, 1992; Olsen et al., 1994; Verbruggen et al., 2009). 


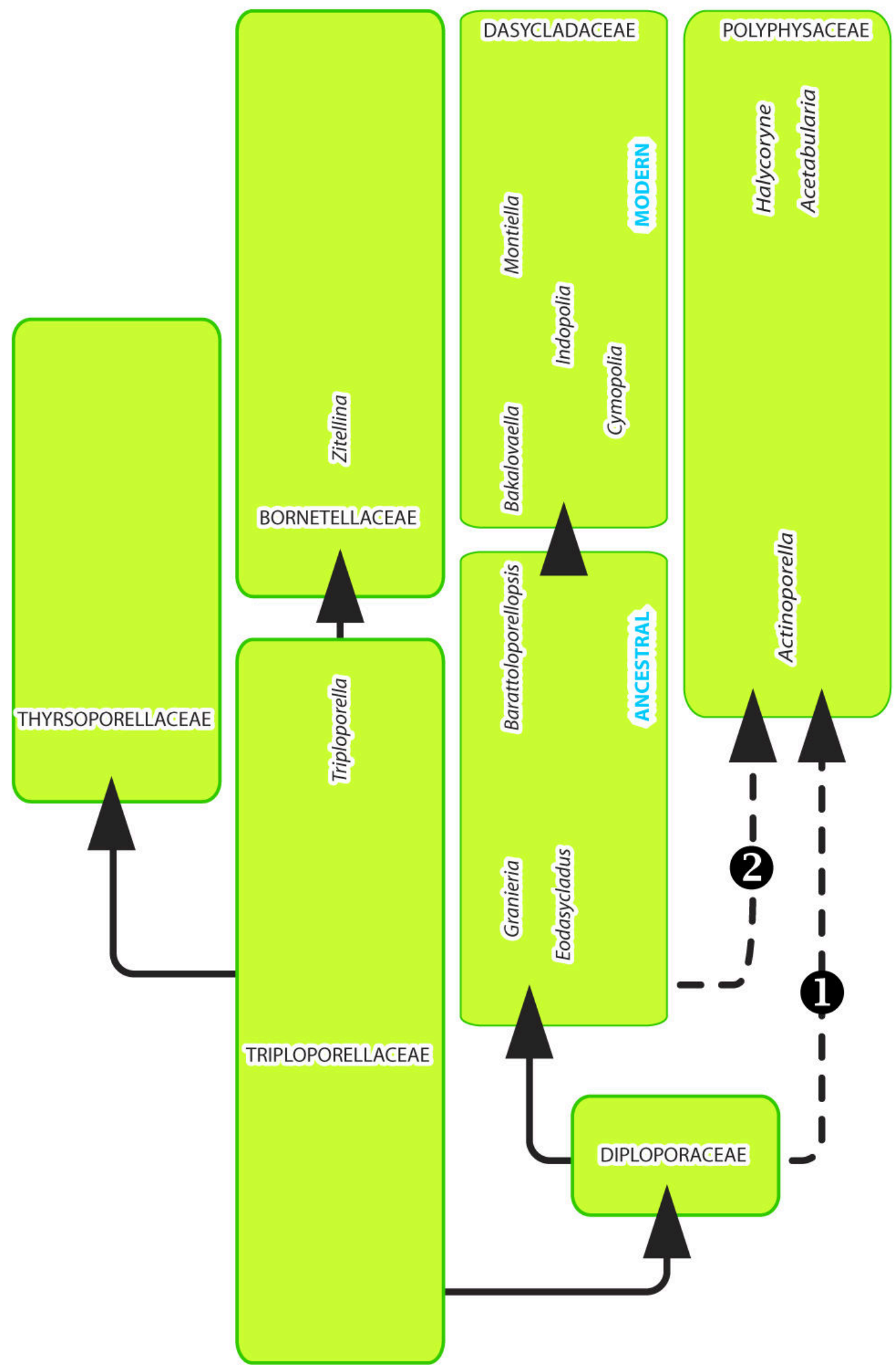

Figure 7: Sketch of a new phylogenetic canvas for the euspondyl Dasycladales (hence excluding the aspondyl Family Seletonellaceae KORDE): 1) hypothesis of a direct filiation of the Polyphysaceae from the Diploporaceae, 2) hypothesis of an indirect filiation of the Polyphysaceae from the Diploporaceae through the "ancestral" Dasycladaceae (favorite hypothesis). 


\section{Conclusions}

With respect to stratigraphy, the Oulad Naïl area requires revision. There are obvious problems as, for instance, when J. EMBERGER (1960: p. 127) cites "Iberina lusitanica(EGGER)" in strata overlying strata with "Calpionellites darderi (COLOM)" at Djebel Zireg. More importantly, EMBERGER's Valanginian and Hauterivian probably refer to Tithonian and Berriasian strata. For instance, and as already pointed out by MAYNC (1959), the Choffatella zireggensis SIGAL, 1952, from the so-called "Hauterivien", is a junior synonym of Anchispirocyclina lusitanica (EGGER); it is nowadays considered a marker of the Tithonian-lower Berriasian interval (e.g., GRANIER, 2019).

With respect to the systematics of the Actinoporellas:

- the type-locality of Actinoporella podolica (ALTH) should be re-sampled in search for specimens approaching the original descriptions of ALTH (1878) and PIA (1920), which is not the case with the material presented by CONRAD et al. (1974);

- although it cannot be demonstrated that Actinoporella podolica (ALTH) is the senior synonym of $A$. lucasi (J. EMBERGER) or of $A$. harrazaensis n.sp., the latter two are well anchored in the genus and should be considered as discrete species.

In addition, Clypeina nigra CONRAD \& PEYBERNÈs is excluded from the Polyphysaceae. It is neither an Actinoporella, nor a Clypeina. A set of evidence anchors it to the Dasycladaceae as Bakalovaella nigra (CONRAD \& PEYBERNÈs), $n$. comb.

With respect to the phylogeny of the Dasycladales, it is assumed that the modern Dasycladaceae and Polyphysaceae, both choristosporate (one with "short ampullae", the other with "long ampullae"/"spicule"), should derive from the fossil Diploporaceae (either indirectly, through ancestral Dasycladaceae, or directly), whereas the modern Bornetellaceae, goniosporate, derive from the Triploporellaceae, which represents a new phylogenetic scenario.

\section{Acknowledgements}

The author would like to thank Phil SALVADOR for his appreciated help with the (English) text. Thanks also go to Ioan I. BUCUR and Felix SCHLAGINTWEIT for their constructive comments on the manuscript.

\section{Bibliographic references}

Alth A. von (1878).- O galicyjskich gatunkach skamieniałych otwornie rodzaju Gyroporella GüMB.Rozprawy i Sprawozdania z Posiedzeń Wydziału Matematyczno-Przyrodniczego Akademii Umiejętności, t. V, Krakowie, p. 71-112 (PIs. VI-VII).

ALTH A. von (1881).- Wapień Niźniowski i jego skamieliny.- Pamiętnik Akademii Umiejętności $w$ Krakowie, Wydział Matematyczno-Przyrodniczy, t. VI, Krakowie, 160 p. (I-XI Pls.). URL: http:// bc.inig.pl:8080/dlibra/docmetadata?id $=54 \&$ from $=$ pubindex\&dirids $=11 \& \mid \mathrm{p}=54$

Alth A. von (1882).- Die versteinerungen des Niźniower Kalksteines.- Beiträge zur Paläontologie Österreich-Ungarns und des Orients, Wien, Band I, p. 183-332.

ARnaud-VAnneau A. (1980).- Micropaléontologie, paléoécologie et sédimentologie d'une plate-forme carbonatée de la marge passive de la Téthys : I'Urgonien du Vercors septentrional et de la Chartreuse (Alpes occidentales).- Thèse, Grenoble; Géologie Alpine, Grenoble, Mémoire H.S., no. 11,874 p.

Berger S., Granier B. \& Bonotto S. (2004).- Dasycladales. Research publications from the beginning until the year 2000.- Koeltz Scientific Books, Koenigstein/Taunus, CD-ROM (085310), $373 \mathrm{p}$.

Berger S. \& Kaever M.J. (1992).- Dasycladales. An illustrated monograph of a fascinating algal order.- Thieme, Stuttgart, $247 \mathrm{p}$.

BUCUR I.I. (2002).- Nouvelles découvertes de Dasycladales fossiles dans les dépôts du Crétacé inférieur de la zone de Reşiţa - Moldova Nouă (Carpates Méridionales, Roumanie).- Acta Palaeontologica Romaniae, Cluj-Napoca, vol. 3, p. 41-52.

Bucur I.I. \& Enos P. (2001).- Middle Triassic dasyclad algae from Guizbou, China.- Micropaleontology, vol. 47, no. 4, p. 317-338.

BUCUR I.I., GRANIER B. \& SĂSĂRAN E. (2010).- Zittelina massei n.sp., a new dasycladacean alga from the Lower Cretaceous strata of Pădurea Craiului (Apuseni Mountains, Romania).- Facies, Erlangen, vol. 56, no. 3, p. 445-457.

Bulle J. \& EMBERger J. (1973).- Découverte du Trias moyen dans la région de Titov Veles (Zone du Vardar, Macédoine yougoslave.- Comptes Rendus de l'Académie de Sciences de Paris (Série D), t. 276, no. 24, p 3101-3102.

Bureau de Recherches Géologiques et Minières (2019).- Saint Trosse 1.- Dossier du sous-sol BSS002AZBB 08745X0007/STE1. URL: http:// infoterre.brgm.fr/search/search.htm (last accessed on $16 / 04 / 2019$ ) 
CANÉRot J. \& Emberger J. (1970).- Découverte du faciès à Mélobésiées dit "Faciès de Vimport" dans l'Albo-Aptien des Chaînes ibériques (Espagne).- Compte rendu sommaire des Séances de la Société Géologique de France, Paris, fasc. 5, page 160.

Conrad M.A. \& Peybernès B. (1976).- Hauterivian-Albian Dasycladaceae from the Urgonian limestones in the French and Spanish eastern Pyrenees.- Geologica Romana, vol. $X V$, p. 175-197.

ConRad M.A. \& Peybernès B. (1978).- Sur quelques Dasycladales de I'Urgo-Aptien du Prébalkan bulgare.- Compte rendu des Séances de la Société de Physique et d'Histoire naturelle de Genève (nouvelle série), vol. 12 (1977), nos. 2-3, p. 69-86.

CONRAD M.A., PRATURLon A. \& RAdoičić R. (1974).- The genus Actinoporella GUEMBEL in ALTH 1882, Dasycladales, green Algae. A revision.- Geologica Romana, vol. XIII, p. 115.

ELLIOTT G.F. (1989).- The evidence of reproductive mechanisms in fossil Dasyclads (Algae: Chlorophyta).- Biological Reviews, vol. 64, no. 3, p. 269-275.

EMBERGER J. (1956).- Les Clypéines (Algues siphonées verticillées) des Monts des OuladNaïl, Atlas saharien, Algérie.- Bulletin de la Société Géologique de France (Série 6), Paris, vol. V (1955), no. 7-9, p. 543-552 (PI. XXIV).

EMBERGER J. (1958a).- Lithoporella elliotti nov. sp., Mélobésiée nouvelle du Jurassique des monts des Oulad-Naïl, Atlas saharien (Algérie).- Bulletin de la Société Géologique de France (6e série), Paris, t. VII (1957), fasc. 6, p. 625-629 (PI. XXXII).

EMBERGER J. (1958b).- Note préliminaire sur les faciès à Algues du Carbonifère du Sahara occidental.- Compte rendu sommaire des Séances de la Société Géologique de France, Paris, no. 2, page 16.

EMBERGER J. (1958c).- Note préliminaire sur les faciès à Algues du Permien du Dj. Tebaga (Sud tunisien).- Compte rendu sommaire des Séances de la Société Géologique de France, Paris, no. 3, page 49.

EMBERGer J. (1960).- Esquisse géologique de la partie orientale des Monts des Oulad Naïl (Atlas saharien, Algérie).- Publications du Service de la Carte géologique de l'Algérie (Nouvelle Série), Alger, Bulletin no. 27, 400 p.

EMBERger J. (1976).- Les Algues (Chlorophyceae, Prasinophyceae, Rhodophyceae) du Carbonifère et du Permien. Essai d'un inventaire bibliographique, géographique, stratigraphique.- Bulletin de l'Institut de Géologie du Bassin d'Aquitaine, Talence, no. spécial, $167 \mathrm{p}$.

EMBERGER J. (1978).- Les Algues (Chlorophyceae, Prasinophyceae, Rhodophyceae) du
Dévonien. Essai d'un inventaire bibliographique, géographique, stratigraphique.- Bulletin de l'Institut de Géologie du Bassin d'Aquitaine, Talence, no. spécial, $94 \mathrm{p}$.

Emberger J. (1979).- Les Algues (Euchlorophyceae, Prasinophyceae, Rhodophyceae) du Trias. Essai d'un inventaire bibliographique, géographique, stratigraphique.- Bulletin de l'Institut de Géologie du Bassin d'Aquitaine, Talence, no. spécial, $157 \mathrm{p}$.

Emberger J. \& JAfFrezo M. (1975).- Compléments à un essai d'inventaire des algues Dasycladacées du Jurassique et du Crétacé inférieur.- Bulletin de l'Institut de Géologie du Bassin d'Aquitaine, Talence, no. 18, p. 59-132.

EMBERGER J. \& MAGNÉ J. (1957).- Observations sur les niveaux à charophytes de l'Aptien des Monts des Oulad-Naïl (Atlas saharien, Algérie).- Bulletin de la Société Géologique de France (Série 6), Paris, vol. VI (1956), no. 7-9, p. 1029-1039.

EMBERGER L. (1944).- Les plantes fossiles dans leurs rapports avec les végétaux vivants (éléments de paléobotanique et de morphologie comparée).Masson, Paris, $492 \mathrm{p}$.

EMBERGER L. (1968).- Les plantes fossiles dans leurs rapports avec les végétaux vivants: Éléments de paléobotanique et de morphologie comparée ( $2^{\mathrm{e}}$ édition).- Masson, Paris, $759 \mathrm{p}$.

GRANIER B. (1989).- Zergabriella, un nouveau genre d'algue dasycladale du Portlandien-Valanginien.Revue de Micropaléontologie, Paris, vol. 32, no. 2, p. 126-133

Granier B. (1992).- Les algues et foraminifères benthiques du Jurassique supérieur et du Crétacé inférieur du Sénégal.- Journal of African Earth Sciences, vol. 14, no. 2, p. 239-253.

Granier B. (1994).- The genus Actinoporella (GüMBEL in ALTH, 1881) and its representatives. A review.- Proceedings of the International Symposium and Field-Meeting "Alpine Algae '93".Beiträge zur Paläontologie, Vienna, no. 19, p. 113-127.

Granier B. (2010).- Bucurella, a new genus of the Thyrsoporelleae (fossil Dasycladalean algae).Carnets Geol., Madrid, vol. 10, no. A03 (CG2010_A03), p. 1-27.

Granier B. (2018a).- Cylindroporella sugdeni ELLIOTT, 1957, an Early Cretaceous Middle-Eastern Dasycladalean alga. A revision.- Journal of Micropaleontology, vol. 37, p. 181-190.

Granier B. (2018b).- A new and unique bodyplan in fossil Bryopsidales, with description of Jaffrezocodium bipennatus n.gen., n.sp., an (?) AlbianCenomanian calcareous green alga.- Cretaceous Research, vol. 85, p. 207-213.

GRANIER B. (2019).- Dual biozonation scheme (benthic foraminifera and "calcareous" green algae) over the Jurassic-Cretaceous transition. Another plea to revert the system boundary to its historical ORBIGNY's and OPPEL's definition. In: GRANIER B. (ed.), VSI: Jurassic-Cretaceous Transition.Cretaceous Research, vol. 93, p. 245-274. 
Granier B., Azerêdo A. \& Ramalho R. (2017).Taxonomic revision of Cylindroporella ? Iusitanica RAMALHO, 1970: In search for the origins of the Family Dasycladaceae.- Island Arc, vol. 26, no. 3, 9 p.

GRANier B. \& BUCUR I.I. (2019).- Le genre Bakalovaella Bucur, 1993 (Dasycladeae, Dasycladaceae), et description de son plus ancien représentant crétacé.- Carnets Geol., Madrid, vol. 19, no. 1, p. 1-19.

Granier B., Dias-Brito D., Bucur i.I. \& Tibana P. (2013).- Brasiliporella, a new mid-Cretaceous dasycladacean genus: The earliest record of the Tribe Batophoreae.- Facies, Erlangen, vol. 59, no. 1, p. 207-220.

LEMOINE M. \& EMBERGER J. (1967).- Kymalithon, nouveau genre de Mélobésiée de l'Aptien supérieur et considérations sur l'âge du faciès à Mélobésiées dit "faciès de Vimport".Actes de la Société Linnéenne de Bordeaux (Série B), t. 104, no. 9, p. 3-14 (Pls. I-IV).

MASSE J.-P., BuCUR I.I., Virgone A. \& Dalmasso H. (1999).- Nouvelles espèces de Dasycladales du Crétacé inférieur de Provence (S.E. France).- Revue de Micropaléontologie, Paris, vol. 42, no. 3, p. 159-168.

Mamet B. \& Roux A. (1981).- Note sur les Albertoporellinae (Dasycladaceae).- Revue de Micropaléontologie, Paris, vol. 23, no. 2-4, p. 231-243.

MAYNC W. (1959).- The foraminiferal genera Spirocyclina and Iberina.- Micropaleontology, vol. 5, no. 1, p. 33-68.

Mouty M. (1966).- Le Néocomien dans le Jura méridional.- Université de Genève, Thèse no. 1369, Université de Damas, Thèse de Doctorat ès Sciences géologiques et minéralogiques, $256 \mathrm{p}$.

Olsen J.L., Stam W.T., Berger S. \& Menzel D. (1994).- 18S rDNA and evolution in the Dasycladales (Chlorophyta) - Modern living fos- sils.- Journal of Phycology, vol. 30, no. 4, p. 729-744.

Peybernès B., Conrad M.A. \& Cugny P. (1979).- Contribution à l'étude biostratigraphique, micropaléontologique et paléoécologique des calcaires urgoniens du Barrémo-Bédoulien Bulgare (Prébalkan et plateforme moésienne).- Revue de Micropaléontologie, vol. 21, no; 4, p. 181-199.

PiA J. (1920).- Die Siphoneae verticillatae vom Karbon bis zur Kreide.- Abhandlungen der zoologisch-botanischen Gesellschaft in Wien, Band XI, Heft 2, $259 \mathrm{p}$.

RADOIČIĆ R. (1969).- A new Lower Cretaceous Dasycladacea, Clypeina pejovici, and note on some Clypeinae.- Geologica Romana, vol. 8, p. 71-84.

REY J. (1972).- Recherches géologiques sur le Crétacé inférieur de l'Estremadura (Portugal).- Thèse de Doctorat d'État, Université Paul Sabatier, Toulouse, 529 p.; Serviços Geológicos de Portugal, Memórias (nova série), Lisbon, no. 21, 477 p. (XXII Pls.).

Schlagintweit F., Dieni I. \& Radoičić R. (2009).Two look-alike dasycladalean algae: Clypeina isabellae MASSE, BUCUR, ViRgone \& DELMASSO, 1999 from the Berriasian of Sardinia (Italy) and Clypeina loferensis sp. $\mathrm{n}$. from the Upper Jurassic of the Northern Calcareous Alps (Austria).Annales géologiques de la Péninsule balkanique, Beograd, vol. 70, p. 43-59.

SigAL J. (1952).- Aperçu stratigraphique sur la micropaléontologie du Crétacé.- XIXe Congrès Géologique International, Monographies régionales (1re Série : Algérie), Alger, no. 26, 47 p.

Verbruggen H., Ashworth M., LoDuca S.T., Vlaeminck C., Cocquyt E., Sauvage T., Zechman F.W., LitTler D.S., LitTler M.M., Leliaert F. \& DE CleRCK O. (2009).- A multi-locus time-calibrated phylogeny of the siphonous green algae.- Molecular Phylogenetics and Evolution, vol. 50, p. 642-653. 


\section{Plates}

Plate 1: a) Actinoporella podolica fide CONRAD et al. (1974: Fig. 6.g); b-f) cf. Clypeina ? isabellae MASSE et al., 1999: b-d) subtransverse sections; e) oblique section of one whorl; f) oblique section with two whorls. Thin sections: b-e) 443, f) 427 (upper Berriasian, Sierra Mariola, Spain, B. Granier Collection); g-aa, ae-aj) Bakalovaella nigra, n.comb. $\mathrm{g}-\mathrm{q}, \mathrm{t}, \mathrm{v}, \mathrm{x}-\mathrm{aa}$, ae, ag-aj) random sections of a single whorls; $r$ ) two isolated whorls; $\mathrm{s}, \mathrm{w}$ ) two connected whorls; $t$, af) oblique sections of two whorls. Thin sections: $g-j, v) 7237 \mathrm{~A} ; \mathrm{k}-\mathrm{I}) 7237 \mathrm{~B} ; \mathrm{m}, \mathrm{o}) 7238 \mathrm{E} ; \mathrm{n}, \mathrm{q}, \mathrm{s}, \mathrm{w}) 7238 \mathrm{~F} ; \mathrm{p}, \mathrm{t}$ ) 7238B; r) 7238A; u, ag, ai-aj) 7237C; $x-y$ ) 7238D; z-aa, ae) 7238C; af, ah) 7237D (Saint-Trosse, France, J. EMBERGER Collection); ab, ak) Bakalovaella nigra, n.comb. Thin section: GT (1) 45 (Rocher de Cluses, France, sequence Ha6 "Urgonian", Gunter TRABOld Collection, D.G.P., Geneva University); ac) Choffatella gr. decipiens SCHLUMBERGER. Thin section: 7237D (Saint-Trosse, France, J. EMBERGER Collection); ad) Palorbitolina lenticularis (BLUMENBACH). Thin section: 7238D (Saint-Trosse, France, J. EMBERGER Collection).

Scale bar $250 \mu \mathrm{m}$. 

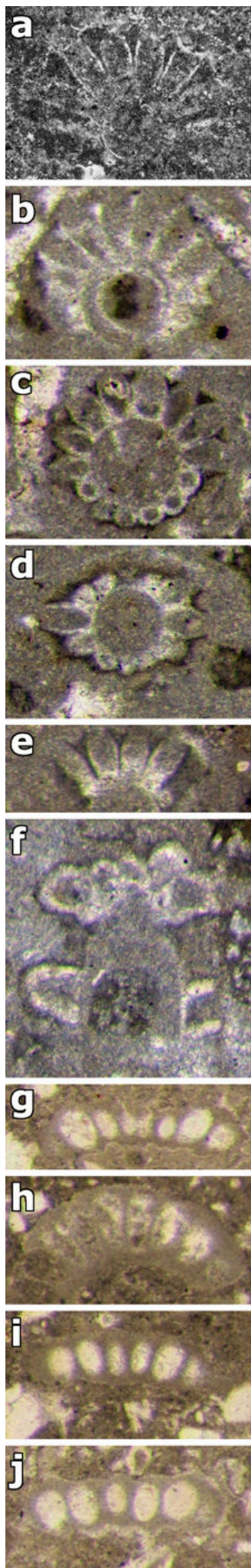

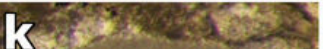
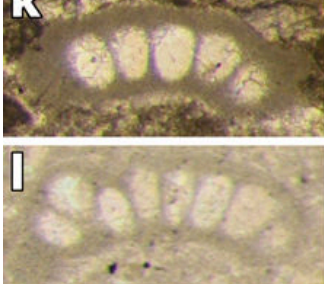
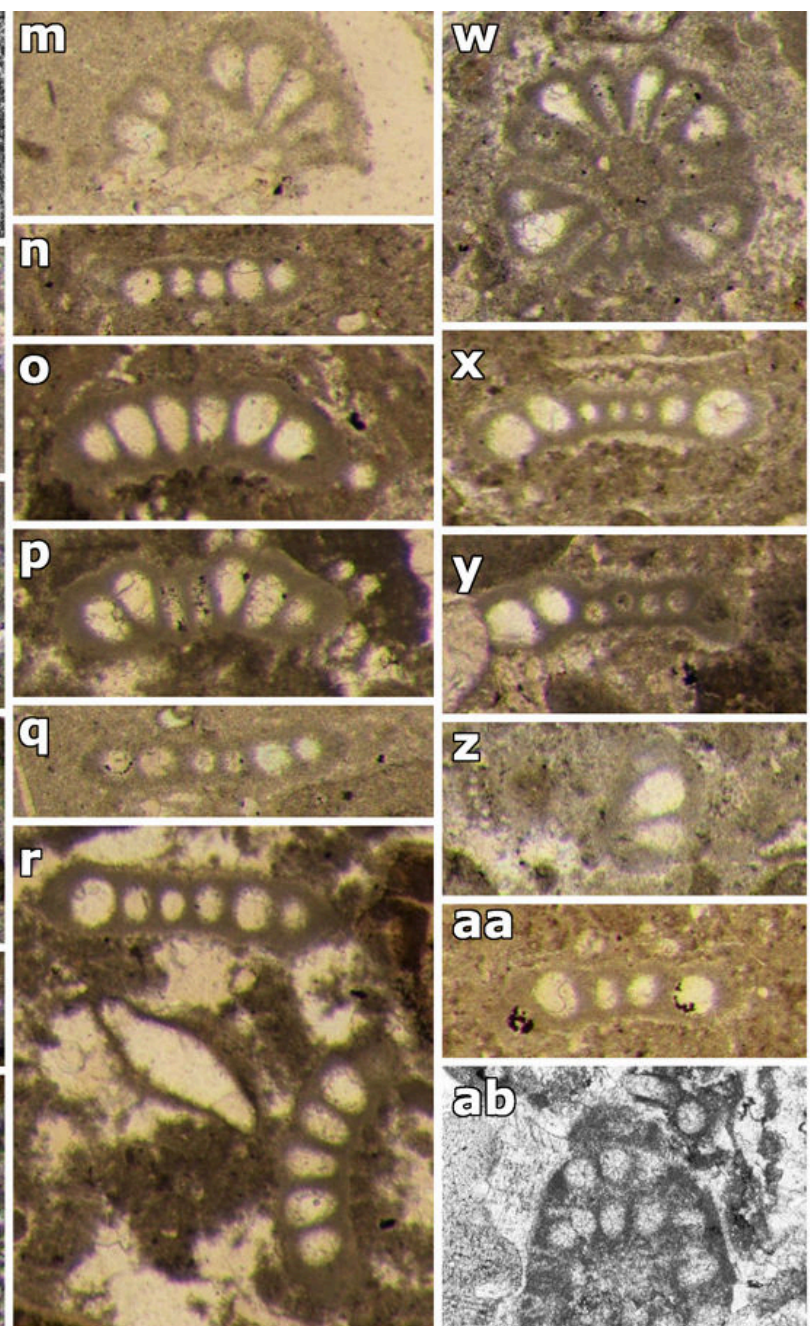

aล

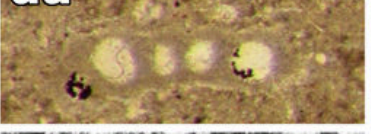

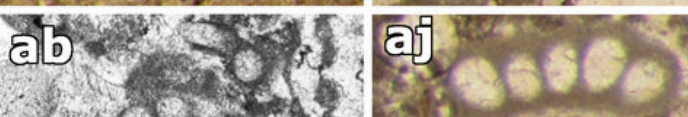

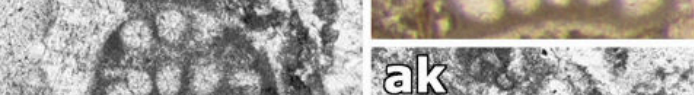

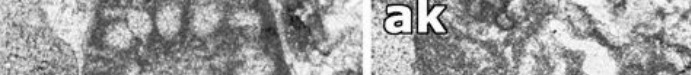
17.

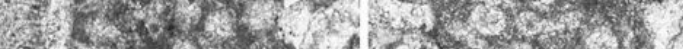
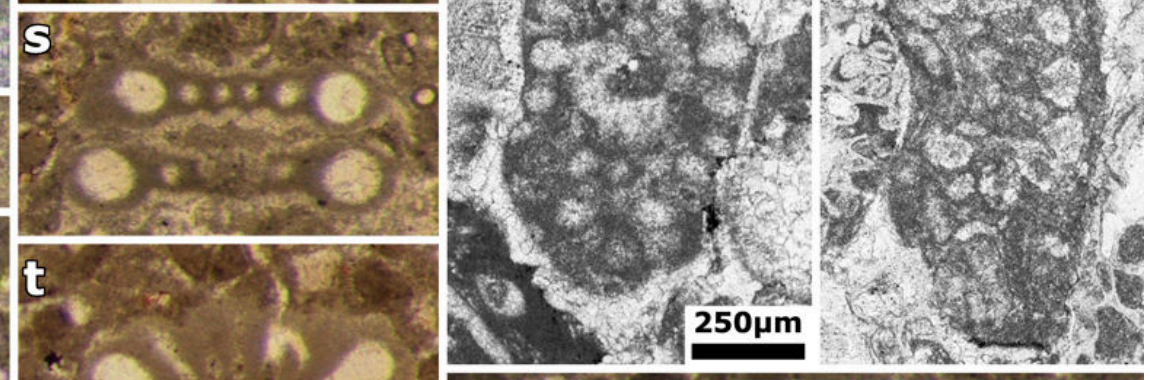

$250 \mu \mathrm{m}$
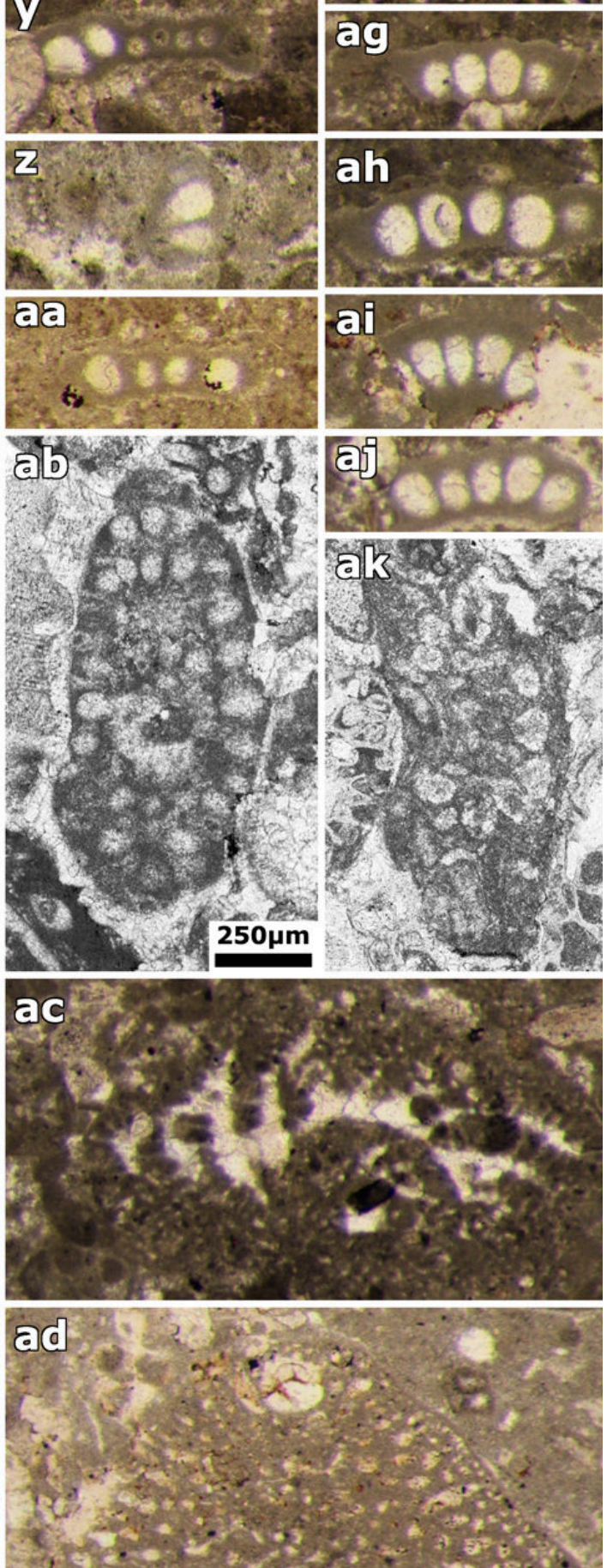
Plate 2: Actinoporella lucasi. a-f) lower and upper side of isolated rows. The distal part of the ampullae is commonly broken. g) The piece of rock after acidic leaching with Actinoporella lucasi, Salpingoporella annulata and Coscinoconus sp. originally illustrated by J. EMBERGER (1956: PI. XXIV, fig. 7). Djebel Zireg, J. EmberGer Collection.

Scale bar $2.5 \mathrm{~mm}$ (except for photo a*: scale bar $250 \mu \mathrm{m}$ ). 


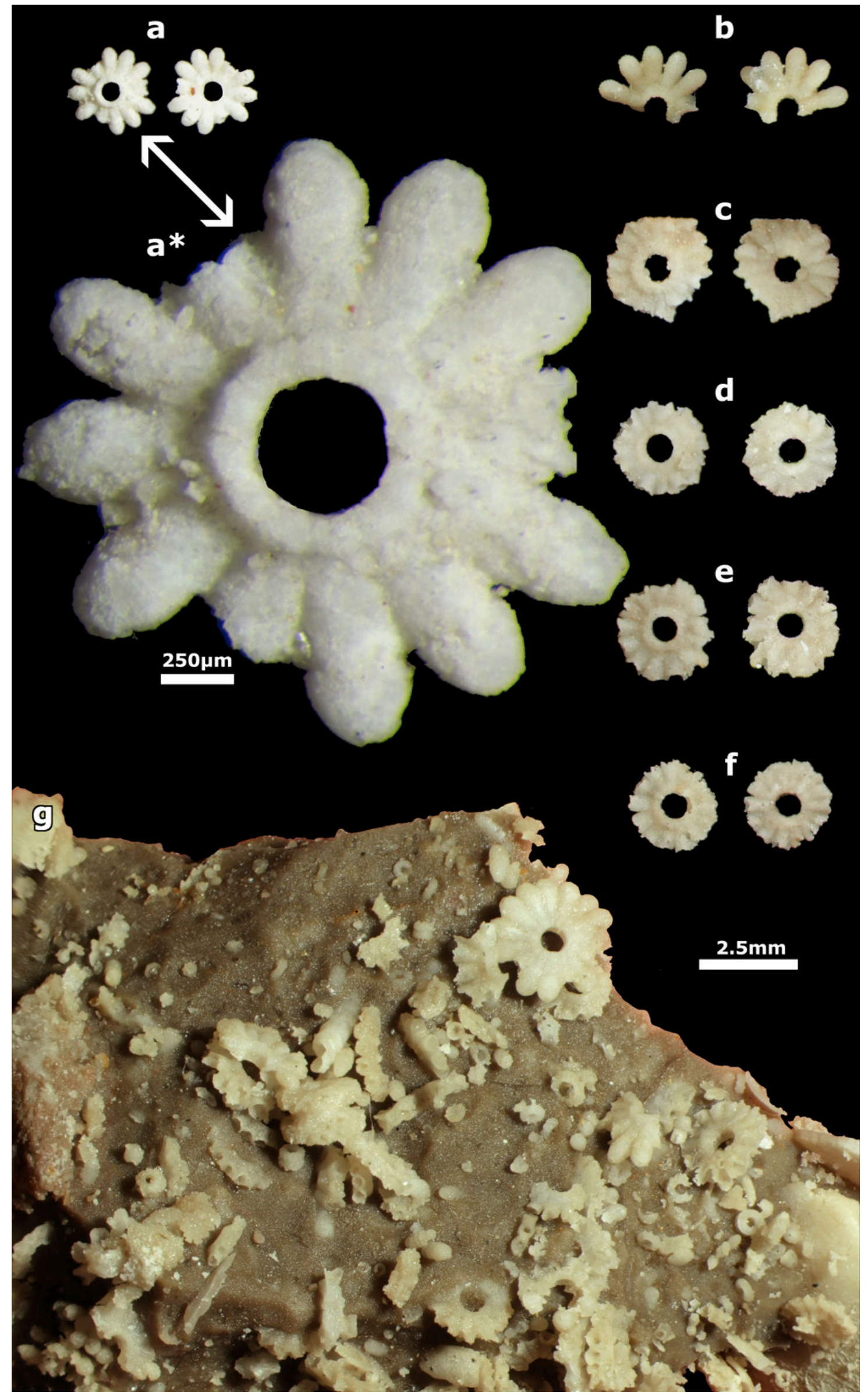


Plate 3: Actinoporella harrazaensis n.sp. a-e) oblique sections of single rows; $\mathrm{f}-\mathrm{h}$ ) tangential sections of single rows. Thin sections: a, d-g) 444A; b-c) 444D; h) 444B (Djebel Harraza, J. Emberger Collection).

Scale bar $250 \mu \mathrm{m}$. 

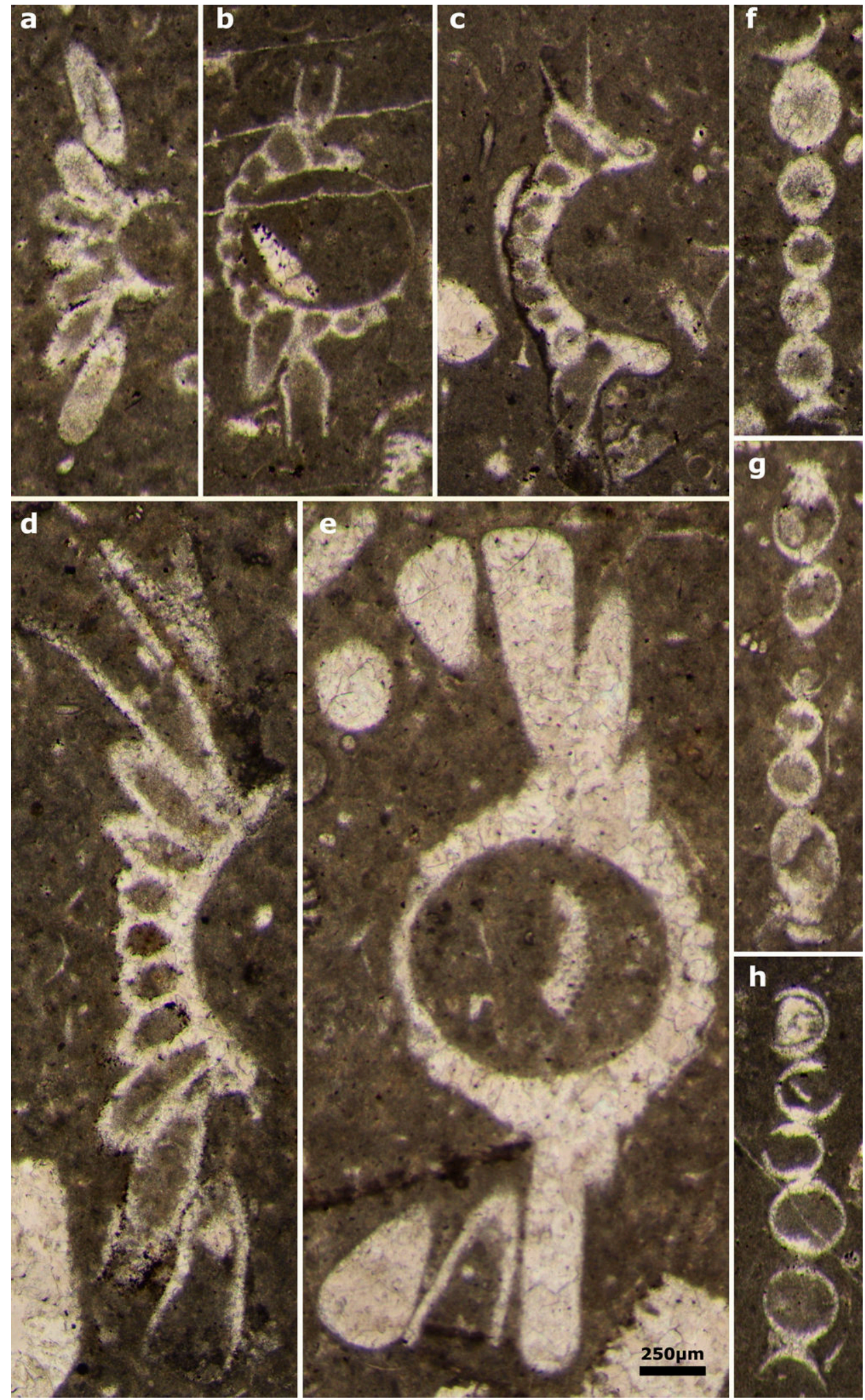
Plate 4: Actinoporella harrazaensis n.sp. a, $\mathrm{f}-\mathrm{g}$ ) deep tangential sections of single row; $\mathrm{b}-\mathrm{e}$ ) subaxial sections of single rows; $h-j$ ) oblique sections of single rows. Thin sections: a-d, g, j) 444B; e) 444D; f) 443A; h) 443B; i) 444E (Djebel Harraza, J. Emberger Collection).

Scale bar $250 \mu \mathrm{m}$. 


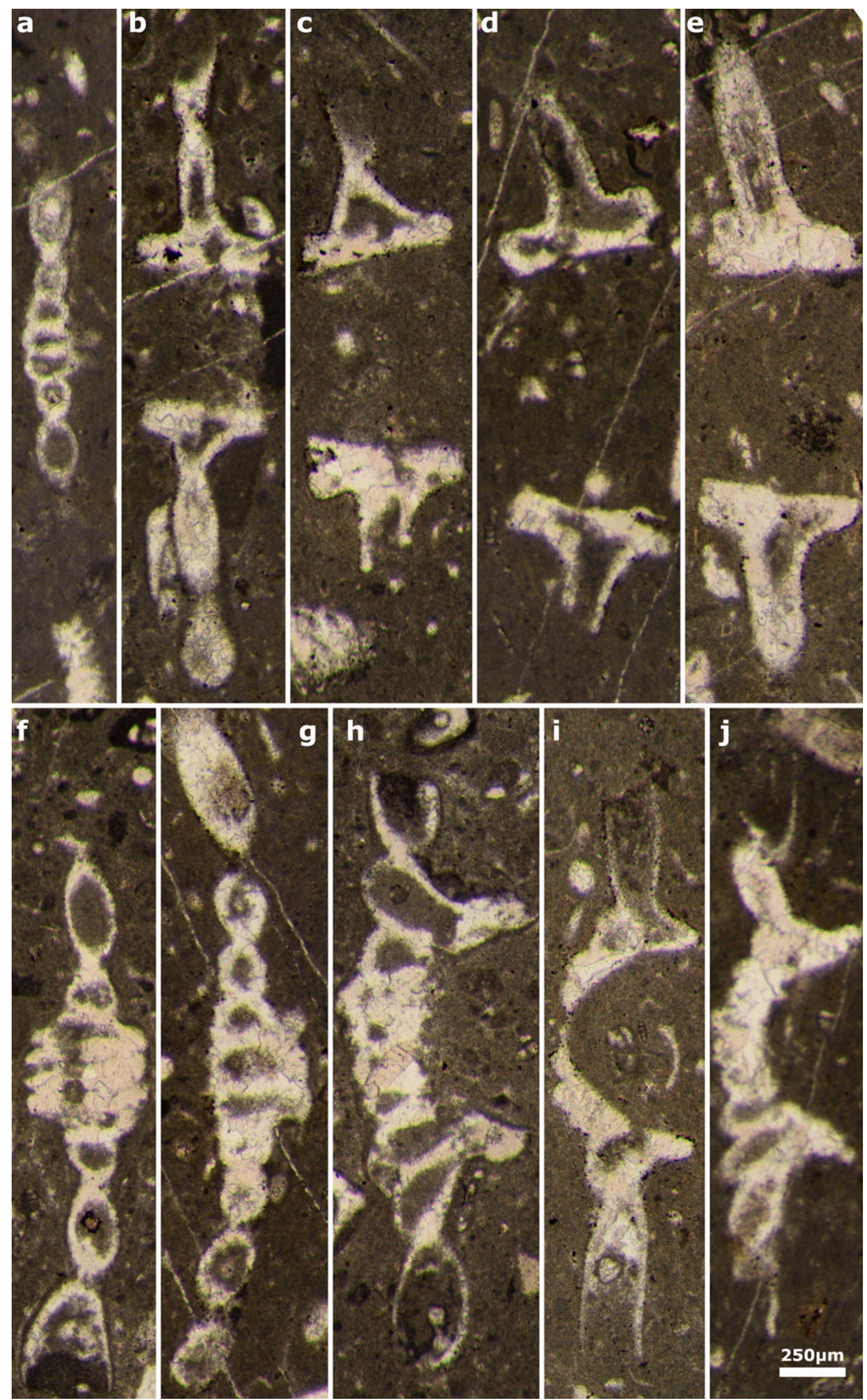


Plate 5: Actinoporella harrazaensis n.sp. a-c) deep tangential sections of single row; d-e) sections of single broken rows; g) subaxial sections of a single row; $h-j$ ) tangential sections of single rows; $k-n)$ oblique sections of single rows. Thin sections: a, I-m) 444E; b, e) 444G; c, g) 444F; d, i, k) 444B; f, j, n) 444D; h) 444A (Djebel Harraza, J. EMBERGer Collection).

Scale bar $250 \mu \mathrm{m}$. 

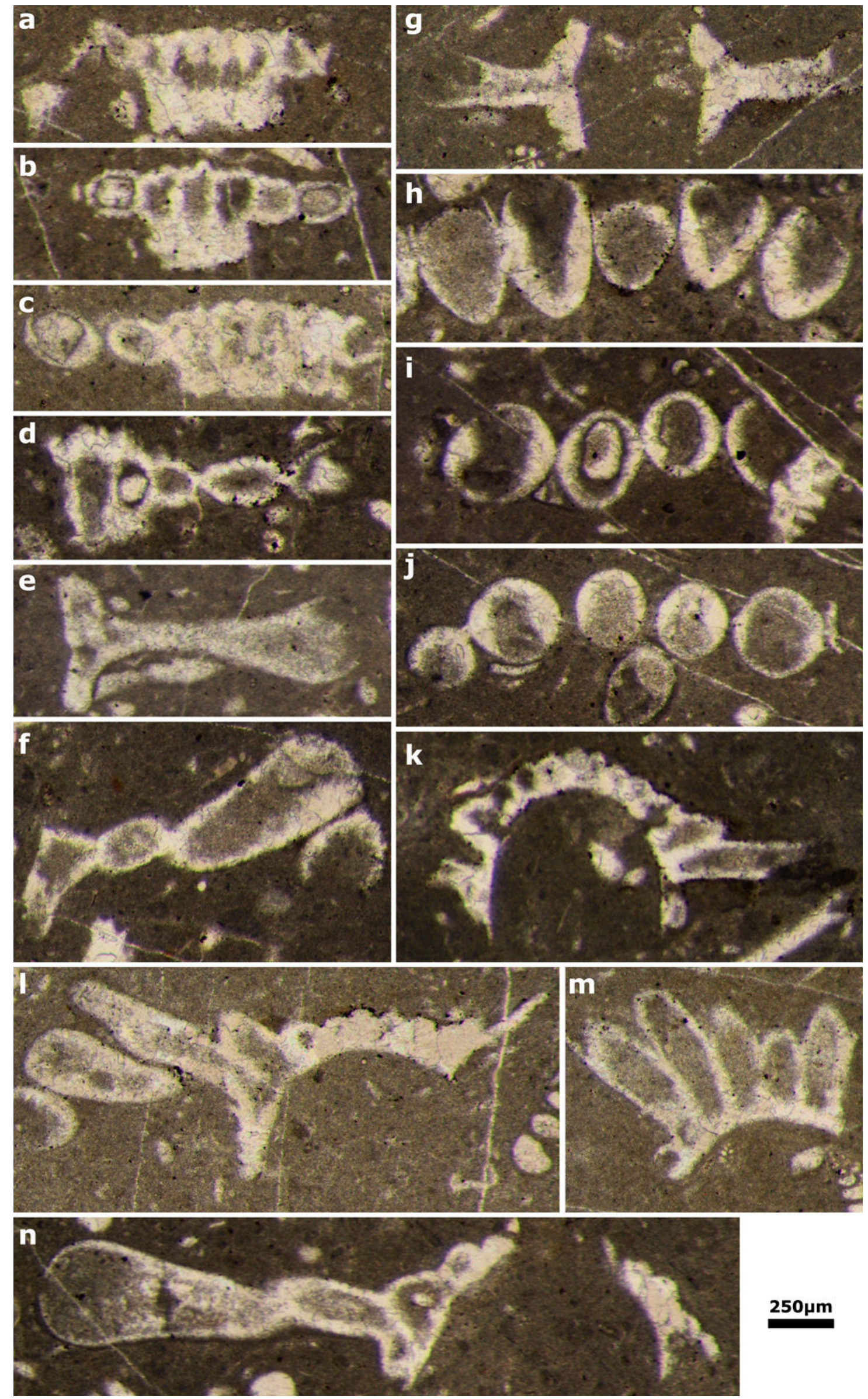

$250 \mu \mathrm{m}$ 
Plate 6: a-d) Actinoporella harrazaensis n.sp.: a-b) oblique sections of single rows; c) tangential to oblique section of a single row; d) subaxial section of a single row (Djebel Ladjdar, Aïn El Melh, J. EMBERGER Collection). e, g-k) Actinoporella lucasi: e) tangential section of a single row. See J. EMBERGER's 1960 Fig. 21; g-h) oblique sections of single rows; i) oblique section of a single row; $j-k$ ) subaxial sections of single rows. f) Calpionellid. Thin sections: $a-b$ ) 873C; c) 873D; d) 873B; e, i-k) 21; f) 873A; g) 19; h) 18 (Djebel Zireg, Aïn El Melh, J. Emberger Collection).

Scale bar $250 \mu \mathrm{m}$. 


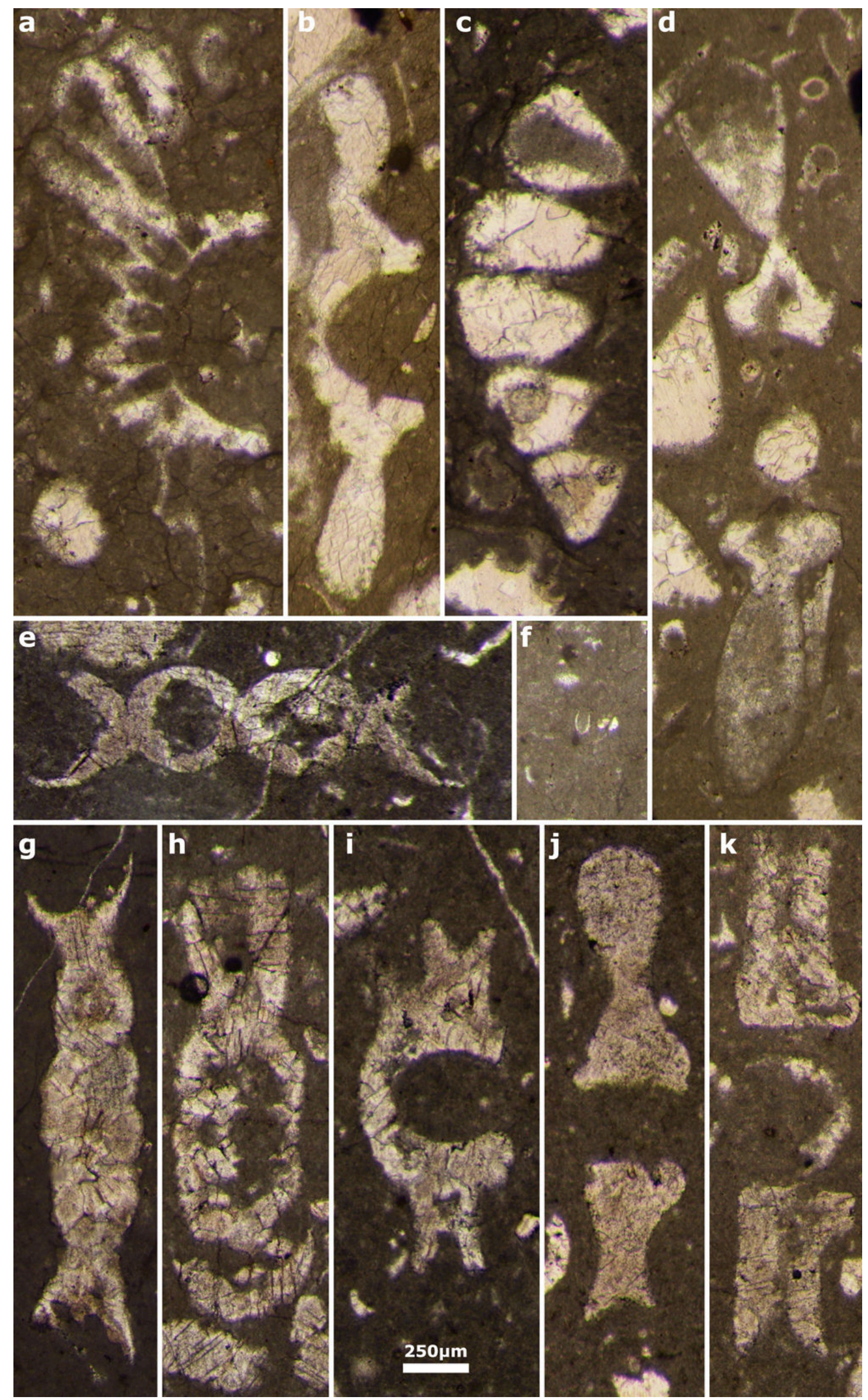


Plate 7: Actinoporella lucasi. a) oblique section of a single row; b) subaxial and tangential sections of two rows; c-f) oblique sections of single rows; g) subtransverse section of a single row. $d$ is used in a drawing of J. EMBERGER (1956: Fig. 3). Thin sections: a-c, f) 21; d) 22; e, g) 18 (Djebel Zireg, J. Emberger Collection).

Scale bar $250 \mu \mathrm{m}$. 

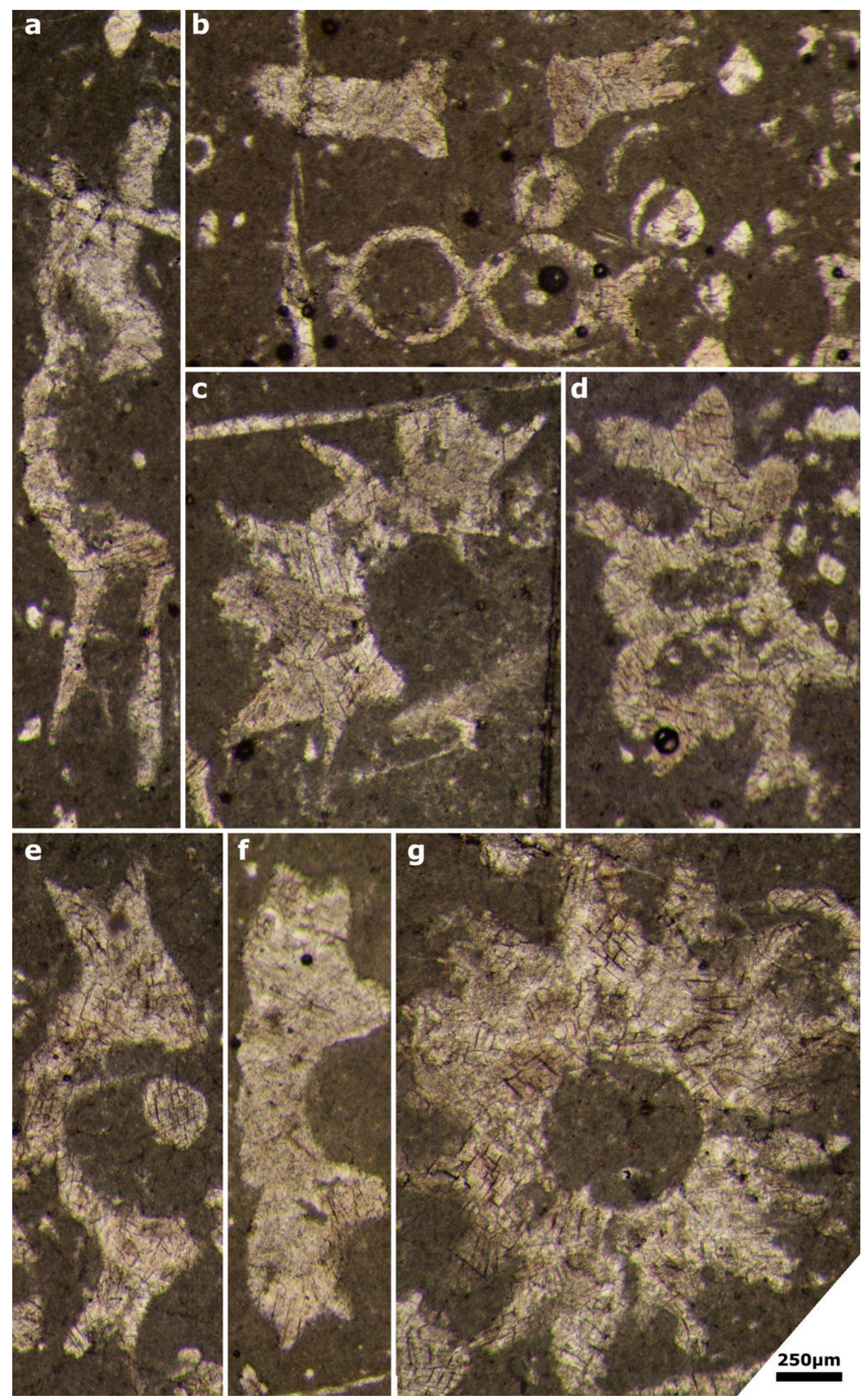
2 